\title{
TRADISI HOSPITALITAS UNTUK PENDIDIKAN PERDAMAIAN DI POSO
}

\author{
Ones Morokuhi \\ Universitas Kristen Indonesia \\ Program Studi Magister Pendidikan Agama Kristen
}

\begin{abstract}
Abstrak
The research in this paper leads to peace education in Poso. Local wisdom approach focus to achieve it. Local wisdom in question is a tradition of cultural in sintuwu maroso and padungku. Researchers considered that culture sintuwu maroso and padungku a primal's hospitality owned Poso then and now. The distinctive feature of this research center at the local wisdom area.

That approach is not without reason. Social unrest conflicts that have occurred in Poso, leaving wounds that are difficult unresolved grudges. Seventeen years ago the conflict was going on, now remaining trauma and feels haunted. Yet the return of all refugees to their original place, not awakening back all the buildings or houses in the former debris destruction mass, separation is expressly settlements Islamic-Christian, social community is still limited, and military approach that is very dominant, not apart from monitoring the author. Watched it is balanced with the security situation, a conducive atmosphere and hospitality of the people of Poso today.

Objectives achieved in this study were (1) to find out how the understanding and meaning of the Poso community's hospitality (2) to find out ways of appreciation and practice of cultural sintuwu maroso and padungku as a form of tradition's hospitality in Poso and (3) to determine the role and the application of hospitality in traditions of cultural sintuwu maroso and padungku for peace education in addressing the conflict in Poso.

The data collection process is conducted qualitatively. Interviews and observations is his method, followed by a description of the data. Analysis of data using analytical approach to Theology-CRE (Christian Religious Education). This approach was chosen because they are the research student of $C R E$.

After conducting research and data analysis as a whole, the picture of hospitality in Poso this time will be presented in a straightforward and unequivocal. Likewise, appreciation and practice of cultural sintuwu maroso and padungku in everyday life. In the end, the author proposes an approach to education for peace in Poso, that is approach through cultural traditions in sintuwu maroso's hospitality and padungku
\end{abstract}

Key words: Hospitality, Sintuwu Maroso, Padungku, Peace Education.

\section{Pendahuluan}

Indonesia merupakan salah satu negara yang sangat plural di dunia. Hal ini terlihat dari adanya 14 etnik utama dan 300 kelompok etnik di dalam kepulauan. Bentang alam geografis dan topografisnya yang terpisah dan terisolasi antar pulau, mendorong bertumbuhnya suku, budaya, ras, dan agama yang beraneka ragam. Saat ini Indonesia memiliki 34 Propinsi, 497 Kabupaten/Kota, 6.651 Kecamatan dan 7.126 Kelurahan/Desa. ${ }^{1}$ Kenyataan inilah yang disebut plural.

\footnotetext{
${ }^{1}$ Badan Pusat Statistik, Hasil Olah Cepat Penduduk Indonesia Menurut Provinsi, Kabupaten/Kota, dan Kecamatan; Sensus
} 
Dewasa ini, pluralitas sering menjadi salah satu penyebab konflik antar suku, ras dan agama di Indonesia. Hampir semua wilayah di Indonesia pernah mengalami hal itu, misalnya konflik di Aceh, Jawa, Kalimantan, Ambon, dan Papua. Mereka bertikai di wilayah itu dengan orang-orang yang berbeda latar belakang. Hal yang sama pun terjadi di Poso. $^{2}$

Pluralitas itu terlihat di mana Poso terdiri dari lima suku besar, yaitu Pamona (suku asli Poso), Bada, Mori, Bali, dan Bugis. Dari lima suku besar itu terbagi lagi ke dalam sub-sub suku masing-masing, misalnya untuk suku Pamona, sub sukunya terdiri atas Longkea, Wingke Mposo, Lamusa, dan Pebato. Jika melihat lima suku besar yang ada di Poso, maka tidak heran bila Poso sangat heterogen termasuk agama/kepercayaannya. Presentase penganut agama di sana adalah: Islam 38\%, Kristen 54\% (Katolik dan Protestan), dan $8 \%$ untuk Hindu dan Budha. ${ }^{3}$

Gejolak-gejolak berdarah di beberapa wilayah di Indonesia hampir saja berakhir. Akan tetapi, sebagaimana di

Penduduk 2010 (Jakarta: Badan Pusat Statistik, 2010), 8.

${ }^{2}$ Tito Karnavian M., Indonesian Top Secret; Membongkar Konflik Poso (Jakarta: Gramedia Pustaka Utama, 2008), 3-13.

${ }^{3}$ Dinas Kependudukan dan Catatan Sipil Kabupaten Poso, Data Pendudukan Kabupaten Poso Triwulan IV Tahun 2015; Keadaan Bulan Oktober sampai dengan Desember 2015 (Poso: Pemda Poso, 2015), 4.
Papua dan Aceh, gejolak berdarah di Poso juga hampir tidak ada habisnya. Kalaupun terjadi penurunan volume konflik, bukan berarti konflik yang telah terjadi selama 17 tahun itu telah berakhir. Di sepanjang tahun 2008-2016 masih saja terjadi konflik-konflik yang mengganggu keamanan dan kerukunan beragama di Poso. Adapun konflik yang dimaksud adalah peristiwa-peristiwa penembakan, pengeboman, penculikan, dan pembunuhan disertai mutilasi terhadap masyarakat sipil ataupun TNI/Polri. Yang terbaru adalah tewasnya pimpinan gembong teroris paling dicari, yakni Santoso disertai penyerahan diri beberapa anak buahnya. Walaupun demikian, Mabes Polri tetap mewaspadai situasi Poso ke depan.

Kabupaten Poso adalah sebuah wilayah di Propinsi Sulawesi Tengah, Indonesia. Secara Geografis, Kabupaten Poso terletak pada $1^{\circ} 24^{\prime}$ Lintang Selatan dan $120^{\circ} 45^{\prime}$ Bujur Timur. Kabupaten ini mempunyai luas sebesar $7.897 \mathrm{~km}^{2}$ dengan jumlah penduduk sebanyak 213.096 jiwa. $^{4}$ Ibukota kabupaten ini terletak di Kota Poso. Kota Poso terletak di bibir pantai menghadap teluk Tomini di salah satu lengkungan 'lengan' pulau Sulawesi. Bila diamati dengan baik, posisi Poso sebenarnya sangat strategis di tengah-

\footnotetext{
${ }^{4}$ Ibid., 1-2.
} 
tengah pulau Sulawesi. Transportasi Utara-

Selatan, yaitu Makassar, Palu-Gorontalo dan Manado, serta Timur-Barat, yaitu Luwuk-Palu, mesti melalui Poso sebagai daerah sentral. Tidak heran bila sebenarnya Poso lebih dahulu dikenal sebagai salah satu kota penting dalam sejarah perdagangan dan pemerintahan di daerah Sulawesi. ${ }^{5}$

Poso saat ini sedang bangkit dari keterpurukannya akibat kerusuhan. Gejolak dan geliat ekonomi pelan-pelan mulai berkembang kembali. Pasar sentral Poso yang dulunya sepi pengunjung, kini sudah ramai kembali - walaupun masih harus tetap waspada. Demikian juga jalanan kota, dulunya sepi, kini ramai kembali -walaupun patroli dan razia Polisi juga masih ramai. Pegawai-pegawai pemerintah ataupun swasta sudah bisa berkantor sampai sore hari bahkan menjelang malam, walaupun terkadang masih saja ada isu-isu teroris. Rumahrumah ibadah yang terbakar saat kerusuhan berdarah, sudah dan sementara dibangun kembali, walaupun tidak bisa lagi dibangun semuanya. Demikian juga dengan rumah-rumah warganya. Pembangunan fasilitas bersama seperti gedung sekolah, rumah sakit, puskesmas, jalan raya dan jembatan kembali

\footnotetext{
${ }^{5}$ Hasrullah, Dendam Konflik Poso; Konflik Poso dari Perspektif Komunikasi Politik (Jakarta: Gramedia Pustaka Utama, 2009), 5.
}

dilanjutkan setelah sempat terhenti selama kerusuhan dan pasca kerusuhan.

Berkaca dari pengalamanpengalaman yang mencekam di Poso, maka menurut penulis pendidikan perdamaian adalah kebutuhan utama secara sosio-psikis di Poso. Pendidikan perdamaian yang berbasis kearifan lokal dalam hal ini menggali hospitalitas Poso melalui budaya sintuwu maroso dan padungku dapat menjadi alternatif. Karena pendidikan yang demikian dapat dirancang, diajarkan dan dievaluasi tingkat keberhasilannya. Apalagi kalau pendekatan pendidikan perdamaian itu dengan menggunakan hospitalitas. Hospitalitas merupakan sesuatu yang ada pada diri seseorang. Hospitalitas adalah modal yang sangat ampuh untuk mengatasi konflik. Hanya saja, sampai sejauh ini modal yang besar itu belum dikaji apalagi diajarkan secara formal maupun non formal. Oleh karena itu, penulis melihat bahwa hospitalitas sebagai salah satu tema dalam pendidikan perdamaian di Poso adalah hal yang sangat diperlukan.

Poso mempunyai banyak tradisi hospitalitas, di antaranya ditemukan pada tradisi sintuwu maroso dan padungku. Hospitalitas adalah sebuah hubungan yang berkualitas di mana terdapat keramahtamahan sebagai ciri utamanya. Keramahtamahan itu terjadi antar anggota keluarga, antar komunitas bahkan antar 
Shanan Jurnal Pendidikan Agama Kristen Vol. 1 No. 12017 |25

lingkungan yang berbeda. Dalam

tamu memiliki kuasa yang sama. keramahtamahan yang demikian dibutuhkan sikap saling terbuka, ramah, hangat, peduli, tulus, harmonis dan saling menghargai. ${ }^{6}$ Sikap khas yang demikian ada dalam tradisi sintuwu maroso dan padungku di Poso.

\section{Kajian Pustaka}

A. Hospitalitas

\section{Pengertian Hospitalitas}

Kata 'hospitality' berasal dari kata Latin 'hospes' yang berarti tamu. ${ }^{7}$ Kata 'hospes' sendiri adalah gabungan dua kata Latin lain, "hostis" dan "pets". Kata "hostis" berarti "orang asing," namun juga memiliki konotasi "musuh." Di sini muncul ambiguitas makna kata; "ia dapat menjadi musuh atau menjadi tamu". Asosiasi makna "orang asing" dan "musuh" di dalam kata "hostis" mungkin muncul karena kemenduaan atau ambiguitas dari orang asing itu sendiri. Dari kata "hostis" itu dikenal kata dalam Bahasa Inggris "hostile" dan "hostility", sedangkan kata "pets" (potis, potes, potentia) berarti "memiliki kuasa." Dari penggalian makna kata "hospes" dapat diartikan bahwa baik tuan rumah maupun

\footnotetext{
${ }^{6}$ James Hastings, Encyclopedia of Religion and Ethics Vol. VI (New York: Charles Scribner's Sons, 1951), 808-820.

${ }^{7}$ Encyclopedia of Religion (Provo, Utah: Macmillan Publishing, 1955), 471.
}

Keduanya layak diperlakukan sekaligus memperlakukan hal-hal yang semestinya. ${ }^{8}$

Kata 'hospitalitas' ini juga dipengaruhi oleh kata Yunani philoxenia

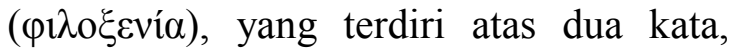
philos atau philia (kasih persahabatan) dan xenos (orang asing). Kata "xenos" menunjuk pada orang asing yang menerima sambutan atau tuan rumah yang melakukan penyambutan terhadap orang lain. Dalam Encyclopedia of Religion and Ethics dipakai kata xenodochēo (xenos dan dechomai) yang berarti "menerima orang asing", "mengasihi orang asing sebagai sahabat" atau "menyahabati orang asing". 9 Maria Harris mendefinisikan hospitalitas sebagai perbuatan menerima yang lain sebagaimana diri mereka sendiri. ${ }^{10}$ Secara sederhana, bisa juga dikatakan bahwa hospitalitas merupakan keterbukaan bagi yang berbeda serta merupakan lawan dari sikap defensif atau eksklusif terhadap yang berbeda.

Dalam hal ini, hospitalitas merupakan perwujudan dari ungkapan rasa kehangatan dalam menerima orang lain, rasa hormat, serta persahabatan dan persaudaraan kepada orang lain, terutama

\footnotetext{
${ }^{8}$ Jesica Wrobleski, The Limits of Hospitality (Minnesota: Liturgical Press, 2012). 15.

${ }^{9}$ James Hastings, Op. Cit., 808.

${ }^{10}$ Ian M. Harris, Fashion Me A People (Louisvelle: John Knox Press, 1989), 87.
} 
kepada tamu yang datang. Jadi, hospitalitas merupakan kesediaan dan sikap membuka diri terhadap kehadiran orang asing/tamu atau kerelaan untuk menerima tamu. Ringkasnya, hospitalitas adalah cinta yang diberikan seseorang kepada orang asing. ${ }^{11}$

Kata "hospitalitas" dalam bahasa Indonesia pada umumnya sama arti dan maknanya dengan "keramahtamahan". "Ramah" berarti "baik hati dan menarik budi bahasanya; manis tutur kata dan sikapnya; suka bergaul dan menyenangkan dalam pergaulan. "Keramahan berarti "sifat ramah; kebaikan hati dalam keakraban. "Ramah-tamah" berarti "amat ramah; pertemuan kekeluargaan (untuk perkenalan dan sebagainya)". Keramahtamahan berarti "hal-hal yang ramah."12

\section{Makna Hospitalitas Keseharian}

Menerima tamu (hospitalitas) tentu bukan kebiasaan yang aneh dalam kehidupan kita. Hampir dalam seluruh kebudayaan masyarakat manusia di dunia dapat ditemukan berbagai tradisi unik dalam menerima dan menjamu tamu atau

\footnotetext{
${ }^{11}$ Michele Hershberger, Hospitalitas-Orang Asing: Teman atau Ancaman? (Jakarta: BPK Gunung Mulia, 2009), 10.

${ }^{12}$ Departemen Pendidikan Nasional, Kamus Besar Bahasa Indonesia Edisi Ke-IV (Jakarta: PT Gramedia Pustaka Utama, 2008). 1136; 1221.
}

orang asing. Tradisi-tradisi seperti ini ada juga di Indonesia. Namun, kadangkala keramahan tidak lagi muncul dari hati. Misalnya saja, saat mengunjungi bank, seseorang akan menerima sapaan pegawai atau pun petugas keamanannya. Kata-kata sapaannya tertata dan seragam, tetapi tanpa rasa dan tidak kontak dengan yang disapa. Mimik wajah dan bahasa tubuh terlihat tidak alamiah. Itu merupakan hasil latihan. Sebaliknya, sekalipun mungkin bukan dengan bahasa "sekolahan", di toko-toko kelontong kecil ataupun di pasar, kita sering lebih merasa hangat disambut. Keramahan yang muncul karena tugas atau dari hati, dapat dirasakan bedanya.

Sikap atau perbuatan hospitalitas juga sangat dibutuhkan dalam perputaran dunia bisnis. Di sana hospitalitas dituntut untuk mendatangkan keuntungan. Seorang atau lembaga produsen harus melayankan hospitalitas kepada calon konsumen. Tujuannya supaya calon konsumen itu mau melaksanakan transaksi jual beli, dan mau menjadi pelanggan tetap karya rasa nyaman dan hangat produsen. Dengan demikian konsumen mengikatkan dirinya dengan produsen. Hospitalitas menjadi komponen penting terhadap kepuasan diri seseorang atau lembaga pelanggang/ 
konsumen. Hospitalis menjadi semacam industri. $^{13}$

Dengan keadaan dan tuntutan seperti itu, hospitalitas berarti berbicara tentang kualitas layanan. Semakin hospitalitas sebuah layanan maka semakin berkualitas pula layanan itu. Dampaknya, seseorang atau produsen yang mempraktekkan hospitalitas dengan standar yang memuaskan akan semakin menambah pundi-pundi keuntungannya. Hospitalitas dipraktekkan hanya sebatas tujuan itu.

\section{Hospitalitas dalam Alkitab}

a. Perjanjian Lama

\section{1) Hospitalitas dalam Tradisi Yahudi}

$\begin{array}{rrr}\text { Orang-orang } & \text { Yahudi } & \text { dalam } \\ \text { Perjanjian Lama } & \text { menyebut } & \text { tradisi }\end{array}$
menerima tamu baik kepada sesama warga maupun kepada orang asing dengan sebutan "hakhnasat orkhim", artinya "membawa masuk para tamu, menjamu para tamu di dalam rumah". ${ }^{14}$ Orang asing yang mau menumpang (menginap) adalah kebal; ia tidak boleh dirugikan, diakali,

\footnotetext{
${ }^{13}$ Pohl, Christine D. "Responding to the Strangers; Insight from the Christian Tradition." dalam Studies in Christian Ethics 19.1 (London: SAGE Publication, 2006), 82.

${ }^{14}$ Harun Darmawanto Simarmata, "Hospitalitas: Warisan Tradisi Kristen: Meretas sebuah Model Pendidikan Kristiani bagi Kehidupan Bergereja di Dunia yang Penuh Perbedaan." Tesis M.Th., STT Jakarta, 2010, 37.
}

dan diperdayai. Tuan rumah harus menjamin dan menjaga jiwa dan raga, kehormatan dan nama, tubuh dan nyawa tamunya. Bahkan jikalau orang asing itu musuh, haruslah dihormati, supaya jangan ia bertindak sebagai musuh. Dengan begitu, mungkin terjadi dari lawan menjadi kawan karena mungkin saja orang asing itu tidak datang sebagai sahabat dan mau menggunakan kuasa saktinya untuk mengutuk seisi keluarga. Barangkali ia seorang dewa yang menyamar sebagai manusia, supaya jangan dikenal, dengan maksud untuk memeriksa dan meneliti seperti pengintai. Tuan rumah wajib menghormati, menguduskan dan memelihara hak dan kebutuhan orang asing. Kekebalan tamu merupakan kewajiban bagi tuan rumah. Rumah yang menerima tamu adalah suatu tempat suaka untuk tamu itu selama mereka berada di dalamnya. Mereka harus menerima perlakuan setia kawan dari tuan rumah. Orang asing harus menikmati perlindungan hukum yang sama dengan tuan rumah/tuan tanah sebagai anak-anak negeri. ${ }^{15}$ Di kemudian hari, hospitalitas diperluas maknanya dari menerima tamu menjadi kepada siapapun, termasuk orang miskin, orang-orang tersisih dan terabaikan, orang

\footnotetext{
${ }^{15}$ Walter Lempp, Tafsiran Alkitab Perjanjial Lama Jilid 3: Kejadian 12:4-15:18 (Jakarta: BPK Gunung Mulia, 1989), 201-202.
} 
asing, dan orang lain yang memiliki status sosial lebih rendah dari pada tuan rumah. ${ }^{16}$

\section{2) Hospitalitas Abraham, Lot, dan Rahab}

Salah satu model pengalaman perjumpaan dengan orang asing yang dicatat dalam Perjanjian Lama adalah pengalaman Abraham berjumpa dengan ketiga orang asing (Kej. 18:1-8). Abraham pernah melayani tiga orang asing itu di kemahnya yang dilakukan dengan penuh rasa iklas. Abraham beserta Sara memberikan hospitalitas yang luar biasa kepada orang asing yang menguji mereka. ${ }^{17}$

Abraham insaf akan kedatangan ketiga orang asing yang tidak dikenalnya. Abaraham tidak mengetahui siapa mereka; Abraham menganggap mereka itu adalah musafir biasa dari negeri yang jauh. Walaupun ia tidak mengenali mereka, meskipun mereka mengganggu waktu istirahatnya pada siang hari, kendatipun Abraham sekali-kali tidak punya kewajiban adat-istiadat terhadap mereka, namun dengan tidak menimbang sekejap mata juga Abraham bangkit dengan segera dari pintu kemahnya, yakni dari tempat duduknya untuk menyambut para tamunya

\footnotetext{
${ }^{16}$ Rabbi Joseph Telushkin, Jewish Literacy (USA: HarperCollins Publisher, 2001), 589.

${ }^{17}$ King Philip J. \& Lawrence E. Stager. Library of Ancient Israel: Life in Biblical Israel (London: Westminster John Knox Press, 2001), 62.
}

itu. Abraham menerima dengan baik serta menunjukkan penghormatan yang tertinggi kepada mereka; Abraham sujud dengan wajahnya menyentuh tanah. Sikap itu ia tunjukkan karena dalam kebiasaan masyarakat pengembara bahwa orang asing mempunyai kesaktian; dapat membawa bahaya yang mengancam. Abraham menerima orang asing itu dan memperlakukannya dengan baik sekali, supaya jangan orang asing itu mempraktikkan kuasanya dan merugikan Abraham. ${ }^{18}$

Abraham menggelari (menyapa) orang-orang asing itu dengan "tuantuanku" yang bersambutan dengan "hambamu" sebagai gelar untuk dirinya sendiri. Dengan ini Abraham menyatakan dirinya siap sedia memberi pertolongan apa saja dan pelayanan kepada orang asing itu. Bentuk jamak dari kata "tuan-tuanku" dalam bahasa Ibrani bersamaan dengan sapaan "Tuhanku". Dengan mengundang dan mempersilahkan orang melarat dan yang haus dahaga itu ke dalam rumah tangganya, maka dengan tidak sengaja Abraham mengundang Tuhan sendiri. ${ }^{19}$

Abraham memberikan minuman dan makanan. Air itu ditawarkan oleh Abraham untuk diminum dan mencuci kaki yang panas dan berdebu. Itulah adat penghormatan yang pertama untuk seorang

\footnotetext{
${ }^{18}$ Lempp, Op. Cit., 200-201.

${ }^{19}$ Ibid., 203.
} 
tamu. Kemudian memberikan tiga sukat makanan. Ukuran itu adalah ukuran untuk raja. Menurut perhitungan biasa, hal itu berarti tiga puluh enam liter tepung, suatu jumlah atau ukuran yang luar biasa besarnya, jika makanan hanya disediakan untuk tiga orang saja ${ }^{20}$ (Lempp 1989, 204205).

Mereka menerima makanan itu, dan dengan demikian mereka menerima baik persahabatan tamu yang ditawarkan Abaraham. Bersama itu mereka mengikat dan mewajibkan diri mereka kepada Abraham dan kaum keluarganya. Mereka sekarang tidak dapat lagi bertindak sebagai musuh, seteru, hantu atau jin, karena mereka sudah pernah makan di dalam rumah tangga Abraham. Persekutuan makan mengadakan dan mendirikan kesejahteraan, keamanan, perdamaian atau perjanjian di antara dua partai. "Lawan" (hostis) telah menjadi "kawan" (hospes). Perseteruan menjadi persahabatan; konfrontasi menjadi konfederasi; pukulan menjadi panduan; perang menjadi damai. Makanan itu bukanlah hanya pengisi perut yang disertai percakapan yang enak, melainkan upacara adat untuk mendirikan persahabatan yang tetap atau untuk mengikat perjanjian. Yahwe Allahnya Israel, yang tersembunyi dalam ketiga orang itu menerima korban Abraham

\footnotetext{
${ }^{20}$ Ibid., 204-205.
}

sambil memakan dan meminum apa yang dihidangkan. Allah memperkenankan korban Abraham dan mengaruniakan perjanjian-Nya kepadanya, yaitu keselamatan. $^{21}$

Lot mempraktekkan hal yang sama ketika ia menerima dua orang tamu (Kej. 19:1-29). Sedari jauh ketika Lot melihat kedua orang itu, ia mengundang tetamu itu untuk menginap di rumahnya karena hari sudah senja menjelang malam. Lot memberikan air pembasuhan kaki dan juga menyediakan makanan dan minuman. Bahkan Lot sampai merelakan kedua anaknya kepada para perusuh yang akan menghardik tamunya. Hospitalitas Lot dalam menerima tamu sangat teruji. Karena itulah, Lot dan keluarganya (kecuali istrinya menjadi tiang garam karena menoleh ke belakang) diselamatkan dari pembumi-hangusan kota Sodom dan Gomora. Hospitalitas Lot disambut Allah dengan memberikan keselamatan. ${ }^{22}$

Hospitalitas lainnya ditunjukan oleh salah seorang perempuan dalam Perjanjian Lama, yaitu Rahab orang Yeriko (Yos. 2:1-24). Rahab mempunyai pekerjaan yang tidak pantas, yaitu perempuan sundal. Dalam profesi seperti itu, melayankan hospitalitas kepada tamu adalah hal yang lumrah. Tentu sebagai balasannya adalah uang. Tetapi ketika dua

\footnotetext{
${ }^{21}$ Ibid., 206-207.

${ }^{22}$ Ibid., 232-239.
} 
orang tamu yang datang dari Israel bermalam di penginapannya, Rahab memperlihatkan hospitalitasnya secara berlebihan. Ia melindungi tamunya dari orang-orang Yeriko yang hendak menangkap tamu tersebut. Padahal Rahab tidak mempunyai kewajiban sedikit pun untuk melakukan hal itu. Kewajiban dan haknya adalah melayani tamu lalu mendapat uang. Tetapi hospitalitas Rahab tidak sebatas transaksi. Ia menyadari bahwa tamu adalah orang yang harus dilindungi, walaupun kekuatannya sebagai perempuan tidak cukup untuk itu. Bahkan ada dalam keyakinanya bahwa tamu yang datang dari Israel itu adalah utusan Allah Israel. Benar saja, hospitalitas perempuan sundal yang menyembah berhala ini disambut oleh Allah dengan memberikan anugerah keselamatan kepada Rahab dan keluarganya. ${ }^{23}$ Hospitalitas yang dramatis dan heroik itulah yang mencatatkan nama Rahab sebagai salah satu nenek dari keturunan Sang Juruselamat, Yesus (Mat. $1: 5)$

b. Perjanjian Baru

\section{1) Hospitalitas dalam Kata Philoxenia}

Hospitalitas dalam Perjanjian Baru berasal dari kata philoxenia ( $\varphi \imath \lambda o \xi \varepsilon v i \alpha)$. Beberapa teks Alkitab yang dapat kita

\footnotetext{
${ }^{23}$ D.C. Mulder, Tafsiran Kitab Yosua (Jakarta: BPK Gunung Mulia, 1990), 22-25.
}

jadikan rujukan, yang secara eksplisit berbicara mengenai hospitalitas pada orang asing. "Bantulah dalam kekurangan orangorang kudus dan usahakanlah dirimu untuk selalu memberikan tumpanganphiloxenia" (Rm. 12:13). "Peliharalah kasih persaudaraan-philadelphia. Jangan kamu lupa memberi tumpanganphiloxenias kepada orang, sebab dengan berbuat demikian beberapa orang dengan tidak diketahuinya telah menjamu malaikat-malaikat" (Ibr. 13:1-2). "Karena itu penilik jemaat haruslah seorang yang tidak bercacat, suami dari satu isteri, dapat menahan diri, bijaksana, sopan, suka memberi tumpangan -philoxenos, cakap mengajar orang" (1Tim. 3:2). Suka memberi tumpangan-philoxenos, suka akan yang baik, bijaksana, adil, saleh, dapat menguasai diri" (Tit. 1:8). "Berilah tumpangan-philoxenos seorang akan yang lain dengan tidak bersungut-sungut" (1Ptr. 4:9). "Tidak jauh dari tempat itu ada tanah milik gubernur pulau itu. Gubernur itu namanya Publius. Ia menyambut kami dan menjamu-xenizō kami dengan ramahnya selama tiga hari” (Kis. 28:7). Salam kepada kamu dari Gayus, yang memberi tumpangan-xenos kepadaku, dan kepada seluruh jemaat. Salam kepada kamu dari Erastus, bendahara negeri, dan dari Kwartus, saudara kita” (Rm. 16:23). "Dan yang terbukti telah melakukan pekerjaan yang baik, seperti mengasuh anak, 
memberi tumpangan-xenodocheō, membasuh kaki saudara-saudara seiman, menolong orang yang hidup dalam kesesakan. Pendeknya mereka yang telah menggunakan segala kesempatan untuk berbuat baik" (1Tim. 5:10). Kata-kata tersebut di atas merujuk pada suatu relasi yang memperkaya atau membangun dari yang asing. ${ }^{24}$

\section{2) Hospitalitas Yesus}

a) Ajaran-Nya

Inti ajaran Yesus adalah kasih (Mat. 22:37-40). Ajaran itu disadur dari tradisi Hukum Taurat di dalam Perjanjian Lama. Pola pelaksanaan Hukum Taurat cenderung memaksa, sedangkan kasih lebih pada ajakan yang lembut. Berbicara tentang kasih tentu berbicara tentang hospitalitas karena di dalam kasih (apalagi kasih yang diajarkan Yesus) tersirat semua unsur dalam hospitalitas. Orang-orang yang mengikuti Yesus berharap Yesus akan mendirikan Kerajaan Allah secara fisik. Kenyataannya, Yesus membangun Kerajaan Allah justru dalam bentuk relasi Allah dan manusia. Allah yang diajarkan Yesus bukan Allah yang menghakimi, justru Allah yang mau bersahabat dengan manusia. "Aku tidak menyebut kamu lagi hamba ... tetapi Aku menyebut kamu

\footnotetext{
${ }^{24}$ Wrobleski, Op. Cit., 15, band. Simarmata, Op. Cit., 24.
}

sahabat" (Yoh. 15:15). Bahkan, Ia menegaskan, "Tidak ada kasih yang lebih besar daripada kasih seorang yang memberikan nyawanya untuk sahabatsahabatnya" (Yoh. 15:13).

Yesus mengajarkan sebuah sudut pandang baru sekaligus berbeda mengenai hubungan dengan Allah dan umat manusia serta manusia dengan sesamanya. Dalam memberitakan kerajaan Allah itu, Yesus berjumpa dengan kelompok-kelompok masyarakat Yahudi pada masa itu dan memberlakukan hospitalitas kepada siapa saja yang Ia jumpai. Di dalam Yesus, kita melihat Allah sebagai tuan rumah the host), yang menawarkan hospitalitas kepada sesama manusia yang membuka diri untuk menerima hospitalitas Allah. ${ }^{25}$

$$
\text { Hospitalitas Yesus juga terlihat }
$$
dalam soal makanan. Ajaran Yesus tentang jamuan makan bertentangan dengan perjamuan tertutup yang berpusat pada hukum kekudusan menjadi perjamuan yang terbuka untuk siapa saja. ${ }^{26}$ Kita melihat dalam narasi-narasi Injil bahwa Yesus duduk makan bersama dengan orang-orang yang dianggap berdosa, sehingga membuat kaum farisi dan para iman mengatakan: "Ia menerima orang berdosa dan makan bersama-sama dengan

\footnotetext{
${ }^{25}$ Simarmata, Op. Cit., 37.

${ }^{26}$ Hope S. Antone, Pendidikan Kristiani Kontekstual; Mempertimbangkan Realitas Kemajemukan dalam Pendidikan Agama (Jakarta : BPK Gunung Mulia, 2010), 28-29.
} 
mereka" (Luk. 15:2). Yesus menerima orang-orang yang berdosa dan Yesus juga diterima oleh orang-orang berdosa. ${ }^{27}$

Perumpamaan Yesus tentang orang Samaria yang baik hati (Luk. 10) bahkan pengalaman Yesus sendiri dengan perempuan Samaria (Luk. 4) menunjukkan betapa Yesus sungguh-sungguh mau terlibat dalam persoalan manusia. Dalam perumpamaan dan pengalaman Yesus itu, Allah memberikan totalitas hospitalitasNya kepada menusia dan juga menerima hospitalitas dari manusia. ${ }^{28}$

b) Pergaulan-Nya

Pola pergaulan Yesus dipenuhi dengan tindakan hospitalitas. Hal ini terlihat umpamanya dari pemilihan kedua belas murid-Nya. Semua murid itu pada awalnya adalah pribadi yang tidak dikenal Yesus. Murid-murid Yesus dari latar belakang berbeda-beda; baik ekonomi, status sosial, pendidikan dan kerohanian. Murid-murid adalah orang-orang yang menerima hospitalitas dari Yesus. Yesus membuka diri dan mau menerima keberadaan murid-murid-Nya. Demikian sebaliknya, murid-murid mau menerima dan mengikuti Yesus. Hospitalitas Yesus disambut hospitalitas para murid. Di sini, hospitalitas Allah datang kepada manusia

\footnotetext{
${ }^{27}$ Simarmata, Op. Cit., 37-38.

${ }^{28}$ band. Hershberger Op. Cit., 67-74.
}

untuk menjadi kawan sekerja dalam misi Allah. $^{29}$

Kepada para pengikut-Nya, Yesus mengajarkan untuk saling menyambut dan menerima antar satu dengan yang lainnya. Yesus juga mengajarkan kepada para pengikut-Nya untuk membuka pintu rumah mereka bagi semua orang bahkan bagi orang miskin dan orang-orang catat. Yesus bersahabat dengan orang-orang yang mempunyai reputasi buruk dalam kehidupan masyarakat: orang samaria, pemungut cukai, perempuan pelacur, dan lain-lain. Injil Sinoptik kaya dengan ceritacerita mengenai hospitalitas yang diberlakukan Yesus. Salah satu contohnya adalah khotbah di bukit. Di dalam teks tersebut berbagai macam orang kayamiskin, lapar, lemah disambut melalui hospitalitas dari Yesus. Yesus digambarkan sebagai earthly host. Yesus menolak cara pandang ordinary host yang mengundang teman-teman, rekan atau kolega, dan tetangga-tetangga yang kaya. ${ }^{30}$

\section{3) Hospitalitas di Kisah Pentakosta}

Kisah Para Rasul yang meneruskan Injil Lukas mengawali kisah-kisah perjalanan misi para murid, khususnya Paulus, dengan kisah Pentakosta (Kis. 2:113). Ketika para murid bersembunyi di

\footnotetext{
${ }^{29}$ Simarmata, Op. Cit., 34.

${ }^{30}$ Pohl, Op. Cit., 20-21 band. Simarmata, Op. Cit., 37.
} 
dalam ketakutan, Roh Kudus hadir sebagai

"lidah-lidah seperti nyala api yang bertebaran dan hinggap pada mereka masing-masing" (ay. 3). Roh yang satu hadir dalam lidah yang banyak dan beragam. Akibatnya, "penuhlah mereka dengan Roh Kudus, lalu mereka mulai berkata-kata dalam bahasa-bahasa lain" (ay. 4). Kunjungan Allah yang sebelumnya berlangsung di dalam Kristus, kini berlangsung melalui Roh Kudus. Hati yang berkobar di dalam kisah Emaus mendapatkan paralelnya di dalam pengalaman kepenuhan oleh Roh Kudus di dalam kisah Pentakosta. Juga, keberanian dan semangat kedua murid Emaus untuk bercerita paralel dengan keberanian para murid Pentakosta berkata-kata dalam bahasa lain (glossolalia). Melalui para murid itu, "perbuatan-perbuatan besar yang dilakukan Allah" (ay. 11) disampaikan. Allah mengunjungi bangsabangsa melalui kuasa Roh Kudus yang hadir di dalam diri para murid. Singkatnya, jika di dalam kisah Emaus, Allah menjadi Tuan Rumah atau Nyonya Rumah bagi manusia, di dalam kisah Pentakosta, Allah menjadi Tamu bagi bangsa-bangsa. Atau, melalui Kristus, Allah menyambut manusia sebagai tamu-tamu-Nya; melalui Roh Kudus Allah disambut sebagai Tamu bagi bangsa-bangsa. ${ }^{31}$

\footnotetext{
${ }^{31}$ Joas Adiprasetya, "Hospitalitas: Wajah Sosial
}

\section{4) Hospitalitas Paulus}

Paulus pada awalnya adalah orang yang sangat membenci orang Kristen. Setelah namanya berganti dari Saulus menjadi Paulus, ia justru sangat berhospitalitas kepada orang-orang Kristen. Peristiwa itu dimulai di kota Damsyik ketika Tuhan "berhospitalitas" kepadanya. Dia yang tadinya "orang asing" kini menjadi salah satu "tuan rumah" dalam pekerjaan pemberitaan Injil.

Dalam perjalanan pastoralnya, Paulus menerima banyak hospitalitas dari jemaat yang dikunjunginya. Ia diterima baik, bahkan ia kadang mendapat hospitalitas secara istimewa. Sikap hospitalitas Paulus yang paling menonjol adalah seruannya mengenai relasi orang Yahudi dan non Yahudi. Di dalam suratnya kepada jemaat di Roma, Paulus memberitakan suatu Injil yang berisi tentang "tidak ada perbedaan" antara Kristen Yahudi dan Kristen bukan Yahudi.

Bentuk hospitalitas yang disampaikan oleh Paulus adalah memberikan ruang demi suatu relasi antar orang-orang Yahudi bukan Yahudi dalam sebuah sikap terbuka menerima yang membangun antar kedua kelompok tersebut sebagai manusia dan saudara di dalam Kristus. Pada masa itu, orang

Gereja Masa Kini." http://gkipi.org/hospitalitaswajah-sosial-gereja-masa-kini/ (diakses tanggal 18 Februari 2016). 
Kristen bukan Yahudi dianggap sebagai orang asing. Paulus menegaskan bahwa istilah philadelphia (kasih terhadap saudara) mesti diimbangi dengan philoxenia -kasih terhadap orang asing. Artinya, kasih terhadap orang Kristen Yahudi sama kadarnya dengan kasih terhadap orang Kristen bukan Yahudi. Paulus menekankan penerimaan yang membangun satu dengan yang lainnya. ${ }^{32}$ Surat kepada jemaat Roma menegaskan bahwa jemaat Roma (Rm. 14:15) menerima yang berbeda atau yang lain dan menahan diri dari menghakimi yang lain. ${ }^{33}$

\section{B. Tradisi Hospitalitas di Poso}

\section{Sintuwu Maroso}

Sejak tahun 1952, sintuwu maroso sudah menjadi motto/falsafah hidup yang sudah dicanangkan oleh Pemerintah Daerah Kabupaten Poso. Motto/falsafah ini dimaksudkan oleh pemerintah untuk merangkul komunitas yang berbeda-beda yang tinggal di Kabupaten Poso. Perbedaan agama dan suku kiranya dapat diakomodir dalam falsafah ini, untuk kemudian digunakan sebagai kekuatan yang kuat untuk membangun Poso.

\footnotetext{
${ }^{32}$ Simarmata, Op. Cit., 40-41.

${ }^{33}$ Lawrence O. Richards, Christian Education: Seeking to Become Like Jesus Christ (Michigan: Zondervan Publications, 1975), 242.
} a. Pengertian dan Makna Sintuwu
Maroso

Sintuwu Maroso dirangkai dari bahasa Bare'e; bahasa nenek moyang orang-orang Poso. Kedua kata ini artinya masing-masing berbeda. Sintuwu berarti setuju atau bersatu. Maroso artinya kuat. Jiwa sintuwu maroso ada pada tuwu malinuwu dan tuwu siwagi. Тижи berarti hidup. Malinuwu berarti sejahtera dan siwagi berarti sederajat. Jadi arti keseluruhannya adalah persatuan yang kuat (akan) membentuk/menciptakan kehidupan yang sejahtera dan sederajat. ${ }^{34}$

\section{b. Cakupan Sintuwu Maroso}

Sintuwu maroso mencakup seluruh kehidupan dan keberadaan orang Poso. Cakupan tersebut umpamanya dalam bertani. Bertani merupakan mata pencaharian utama di Kabupaten Poso dari zaman dahulu hingga zaman modern ini. Teknis proses bertani dari dahulu hingga sekarang belum banyak berubah. Praktek sintuwu maroso masih sangat akrab dilakonkan. Sintuwu maroso pada bidang ini terwujud dalam semangat gotong royong. Dari pembukaan ladang sampai pada panen selalu dilakukan secara gotong royong. Kata 'kita' memberi makna bahwa apabila kita secara komunitas bergotong

\footnotetext{
${ }^{34}$ Y. Manyonyo, "Kebudayaan Tana Poso.” Dalam Wajah GKST: Buku Kenangan 100 Tahun Injil Masuk Tana Poso. Dj. Tanggerahi (Tentena: Majelis Sinode GKST, 1992), 106.
} 
royong dalam bertani, maka panen kita akan berhasil. Dengan itu, kita akan mengalami hidup sejahtera secara bersama-sama pula (tuwu siwagi tuwu malinuwu). Di sini berlaku hukum gotong royong. Jika saya rajin bergotong royong, maka saya akan menerima balasannya. Dengan kata lain, orang-orang-akan bergotong royong mengerjakan pertanian saya kalau saya rajin bergotong royong di ladang orang lain sebelumnya. Dalam tradisi orang Poso sistem ini disebut merabe (mengkredit/mengambil dimuka) dan mebolosi (mengganti/ mengembalikan). Kalau saya atau anggota keluarga saya merabe, maka orang lain akan datang mebolosi. ${ }^{35}$ Begitulah siklus Sintuwu Maroso dalam lingkar pertanian. Dan ini terus-menerus berputar tidak lekang oleh waktu.

Cakupan sintuwu maroso yang lain adalah pembangunan infrastruktur umum. Kebiasaan bergotong royong di ladang, kemudian berimbas untuk bergotong royong membangun desa, membangun balai desa, membangun rumah, membangun jembatan, membuat lapangan, membersihkan selokan, dan lain sebagainya.

Menurut Manyonyo, cakupan sintuwu maroso yang tak kalah kuatnya adalah dalam hal mosusa. Hal ini terbagi

${ }^{35}$ Ibid., 107. atas dua macam, yaitu: mosusa mate dan mosusa tuwu. ${ }^{36}$ Mosusa mate terjadi apabila salah seorang dari warga desa meninggal dunia. Pada keadaan yang demikian, yang berduka bukan hanya keluarga dekat, tetapi semua warga dalam satu desa itu. Semua aktivitas di desa itu akan terfokus pada keluarga yang berduka. Aktivitas di ladang (bertani) dihentikan/ditiadakan pada hari duka iu. Semua kebutuhan duka ditanggung bersama. Di sini orang-orang tidak hanya mosintuwu secara fisik dalam arti memberi waktu dan tenaga, tetapi dalam bentuk pemberian dukungan materi/uang. Pelakupelaku sintuwu maroso pada mosusa mate ini, bukan hanya sekedar mengingat jasa dari keluarga yang berduka atau dari orang yang meninggal, tapi sebuah perenungan yang dalam bahwa pada gilirannya 'saya' akan mengalami hal serupa.

Mosusa tuwu terjadi apabila salah seorang atau beberapa orang dari warga desa akan melaksanakan pernikahan. Sudah lazim dipraktekkan apabila 'saya' sebagai tuan pesta belum mempunyai dana yang cukup, maka 'saya' wajib memberikan beban 'saya' kepada warga lain dan terutama kepada kerabat dekat 'saya'. Kewajiban ini disebut posintuwu. Di sini pun berlaku istilah merabe dan mebolosi. Acara persiapan pernikahan atau

\footnotetext{
${ }^{36}$ Ibid., 107-109.
} 
yang disebut molanggo merupakan tempat merealisasikan posituwu itu (baik yang merabe maupun yang mebolosi). Pada gilirannya 'saya' juga akan mosintuwu dengan keluarga pesta lainnya. Dengan demikian spiral mosintuwu tidak akan pernah usai; berputar dan terus berputar tanpa ujung.

Pada pesta mosusa tuwu ini ada rangkaian adat yang namanya ' $a d a$ mporongo'. Adat mporongo tidak boleh dilanggar. Apabila terjadi pelanggaran adat, maka diyakini yang akan bersalah adalah seluruh warga desa. Ada semacam keyakinan bahwa perbuatan seseorang dapat mempengaruhi komunitas. Kehadiran atau keberadaan seseorang dipandang dalam kacamata komunitas/kebersamaan bukan individu/person. Ini merupakan pengaruh dari budaya sintuwu maroso, di mana kehadiran seseorang saling berkait dengan orang lain. Satu orang merupakan bagian yang tidak terpisahkan dari orang lain. Itulah artinya poso (yang diambil dari kata poso'o; ikatan /pengikat bukan poso; maposo (pecah).

Sintuwu maroso juga mencakup hubungan antar agama dan politik. Hubungan yang harmonis antar agama sudah ada sejak dahulu. Contohnya pada tahun 1948 ketika orang-orang Kristen hendak membangun gedung gerejanya, mereka mendapat bantuan dana dan tenaga dari umat Muslim. Dukungan ini diberikan dalam kerangka berpikir posintuwu yang baik. Toleransi antar umat beragama terjalin baik. Pada hari-hari raya agama, umat saling mengunjungi memberi ucapan selamat dan saling memberi parcel.

Di dalam kata sintuwu maroso, tersirat kata kita yang mengantarai keduanya (sintuwu kita maroso). Secara politik, kata 'kita' yang mengantarai sintuwu maroso, juga lebih menunjuk pada orang-orang Poso yang pada saat itu sedang mengalami konflik politik. Lebih tepatnya mereka yang pada saat itu sedang diganggu oleh suku Luwu dari arah Selatan dan suku Sigi dari arah Utara. Kata 'kita' menegaskan bahwa apabila kita orang-orang Poso yang mengandung banyak sub suku mau bersatu, maka kita akan mampu mempertahankan wilayah kita dan tidak akan diganggu lagi oleh suku lain. Karena musuh kita bukanlah suku beserta sub-sub sukunya yang berbeda dan juga bukan agama-agama yang berbeda tetapi peperangan itu sendiri. Musuh kita adalah para penindas, ketidakadilan dan kekacauan. Dengan demikian apa yang diharapkan oleh raja Talasa - raja di Poso yang pertama-dapat dicapai. Harapan raja tersebut dibacakan pada pukul 09.00 WITA di kantor raja Poso pada hari Selasa 11 Mei 1947 yang berbunyi: 
Laut/Teluk Tomini tidak ada pagarnya Laut/Teluk Tomini tidak ada pagarnya Hai kamu orang Poso

Hai kamu orang Arab Hai kamu orang Tionghoa

Hai kamu orang Jawa Hai kamu orang Manado Hai kamu orang Gorontalo Hai kamu orang Parigi Hai kamu orang Tojo Hai kamu orang Ampana Hai kamu orang Bungku Hai kamu orang Bugis orang Wotu Hai kamu orang Makassar ... Tana Poso tidak boleh dikotori.....

\section{Padungku}

a. Pengertian dan Makna Padungku

Padungku berasal dari bahasa Bare'e, yaitu dungku, yang artinya telah selesai/rampung. Penambahan awalan $p a$ pada kata dungku menunjuk pada proses pertanian yang telah selesai dikerjakan. Hal-hal yang telah selesai/rampung dikerjakan itu adalah memetik padi (olu mo), proses menertibkan padi (ri baora) dan proses menyimpan padi (ri poniu). Sebagai ungkapan rasa syukur, sukacita, dan bahagia atas proses yang telah berakhir itu maka diadakanlah padungku. Jadi, padungku adalah perayaan atas proses pertanian yang telah berakhir di tahun tanam berjalan. Sederhananya, padungku adalah ucapan syukur setelah panen raya. Ucapan syukur itu ditujukan kepada Tuhan Pemelihara Alam Semesta yang disebut orang Poso pada awalnya Pue mPalaburu. Di samping sebagai upacara keagamaan, padungku juga dianggap sebagai upacara adat orang Poso dalam siklus pertanian (Hokey 2016). Upacara ini dilakukan setahun sekali oleh semua desa di Poso, khususnya suku Pamona-Poso yang berbahasa Bare'e, terlebih khusus lagi yang bergama Kristen. Jadi, padungku adalah upacara adat sekaligus ucapan syukur tahunan anggota masyarakat yang beragama Kristen di Poso.

\section{b. Keunikan Padungku}

Padungku pada dasarnya adalah acara makan-makan. Acara ini berlangsung sehari, terlaksana di sebuah atau beberapa desa/kelurahan (biasanya 35 desa/kelurahan sekaligus, tetapi ada juga yang hanya satu desa/kelurahan saja). Hari pelaksanaan padungku ditentukan bersama melalui musyawarah antara pemerintah desa/kelurahan dengan pimpinan Gereja lokal (Majelis Jemaat). Dewasa ini padungku berlangsung antara bulan Mei sampai dengan Oktober setiap tahunnya. Selama bulan itu akan dilangsungkan padungku secara bergantian. Jadi selama periode bulan Mei sampai Oktober, padungku bisa terjadi sebanyak 10-15 kali di beberapa tempat.

Pada hari padungku, kegiatan pertama adalah mominggu/mobasa, yaitu beribadah di Gereja. Ibadah merupakan interpretasi dari ungkapan syukur karena Allah telah memberikan keselamatan dan 
berkat dalam proses pertanian (ataupun mata pencaharian lain) selama setahun. Ibadah menjadi sangat penting, karena para petani (ataupun profesi lain) meyakini bahwa Tuhanlah yang telah menyertai mereka dalam pekerjaan. ${ }^{37}$

Selesai mominggu/mobasa barulah masuk pada acara mangkoni/mopancua artinya makan. Makanan dan minuman disediakan secara prasmanan. Dengan bergantian tamu-tamu akan mengunjungi rumah kerabat-kerabat dekatnya bahkan rumah dari orang-orang yang tidak dikenal sekalipun. Tamu akan datang dari segala tempat, baik yang dari wilayah pegunungan atau pun dari wilayah pesisir laut. Tamu tidak terbatas pada yang beragama Kristen saja, tapi yang beragama Islam pun atau agama lainnya boleh datang untuk menghadiri dan merayakan padungku. Tuan/nyonya rumah akan mempersilahkan tamunya untuk bersantap, baik yang dikenal maupun yang tidak dikenal. Untuk tamu yang non Kristen, biasanya tuan/nyonya rumah telah menyediakan makanan yang diolah khusus untuk mereka. Tuan/nyonya rumah akan merasa sangat bersukacita bila tamunya banyak yang datang dan menikmati hidangan yang ada. Tidak ada batasan untuk ukuran porsi makanan. Siapa saja boleh makan sesuai selera dan

\footnotetext{
${ }^{37}$ Hengky Ompi, Wawancara oleh Penulis. Poso (Tentena), Indonesia, 16 Mei 2016.
}

kemampuannya. Sambil makan, tuan/nyonya rumah akan menemani tamunya dengan bersenda gurau, canda tawa dengan penuh keramahan dan kegembiraan. Inilah yang paling khas dari padungku, yaitu bertemunya dan diterimanya apapun dan bagaimanapun keberadaan dan latar belakang seseorang di meja makan padungku. Di situlah kemanusiaan seseorang dijunjung setinggitingginya. Walaupun budaya ini hanya dilaksanakan oleh masyarakat beragama Kristen, tapi dampaknya dirasakan oleh semua pemeluk agama lain di Poso. Karena melalui budaya padungku terjalin tali silahturahmi yang melintasi semua agama. Setiap orang menikmati dan marayakan kehidupannya tanpa sekat perbedaan suku, ras dan agama.

\section{Pendidikan Perdamaian}

\section{Pengertian Pendidikan Perdamaian}

Pendidikan Perdamaian terdiri dari dua kata: "pendidikan" dan "perdamaian". "Pendidikan" berasal dari kata "didik". Kata ini biasanya berawalan "me" sehingga menjadi "mendidik" yang artinya "memelihara," dan "memberi latihan."38 Kata pendidikan dalam bahasa Yunani disebut dengan istilah "paedagogie" diartikan "ilmu dan seni mengajar anak."

\footnotetext{
${ }^{38}$ Poerwadarminta, Kamus Besar Bahasa Indonesia (Jakarta: Balai Pustaka Utama, 1981), 232.
} 
Menurut Kamus Wikipedia Indonesia, pendidikan adalah usaha sadar dan terencana untuk mewujudkan suasana belajar dan proses pembelajaran agar peserta didik secara aktif mengembangkan potensi dirinya untuk memiliki kekuatan spiritual keagamaan, pengendalian diri, kepribadian, akhlak mulia, serta keterampilan yang diperlukan dirinya dan masyarakat (website 2016). Menurut UU No. 20 tahun 2003 Bab I Pasal 1 tentang sistem Pendidikan Nasional, pendidikan adalah usaha sadar dan terencana untuk mewujudkan suasana belajar dan proses pembelajaran agar peserta didik secara aktif mengembangkan potensi dirinya untuk memiliki kekuatan spritual keagamaan, pengendalian diri, kepribadian, kecerdasan, akhlak mulia, serta keterampilan yang diperlukan dirinya, masyarakat, bangsa dan negara.

Dari pernyataan-pernyataan di atas penulis mengartikan bahwa pendidikan adalah usaha sadar dan terencana untuk mewujudkan suasana belajar dalam proses pembelajaran yang bertujuan untuk mempertajam kecerdasan kognitif, emosional dan keterampilan pada satu sisi serta pengendalian diri, kepribadian, peradaban, bahkan kekuatan spiritual keagamaan pada satu sisi lainnya.

Kata berikutnya adalah "perdamaian" dari kata dasar "damai". Istilah "damai" menurut Kamus Besar
Bahasa Indonesia memiliki tiga arti, yaitu: (1) tidak ada perang; tidak ada kerusuhan; aman, (2) tenteram; tenang, dan (3) keadaan tidak bermusuhan. "Perdamaian" berarti tidak bermusuhan atau penghentian permusuhan/perang. Jadi istilah damai atau perdamaian menunjuk pada satu keadaan yang aman, tenteram dan tenang. Aman adalah bebas dari bahaya, bebas dari gangguan, terlindung atau tersembunyi; pasti: tidak meragukan, tidak mengambil resiko; dan tenteram; tidak merasa takut atau kwatir. Istilah aman mengandung arti tidak rusuh; tidak kacau. ${ }^{39}$ Makna damai dapat diartikan lebih luas dari bukan hanya sekedar ancaman fisik, tetapi juga dari ancaman dalam bidang ekonomi, terciptanya keadilan dan hilangnya ketakutan dari individu dan masyarakat.

Ada dua konsep inti dari kata peace dalam peace education, yakni negative peace dan positive peace. Negative peace diartikan di mana tidak adanya kekerasan fisik yang terorganisir, tidak ada perang dan konflik secara langsung. Kondisi tanpa konflik ini diciptakan dengan memunculkan prasayarat-prasyarat antara lain pelucutan senjata serta menjauhkan diskusi dari konflik makro dan mikro. Dalam negatice peace ini terkadang diperlukan kontrol kekerasan yang dilakukan oleh pemerintah melalui

\footnotetext{
${ }^{39}$ Ibid., 301.
} 
pengamanan dan perlindungan. Cara yang juga sering ditempuh adalah dengan memisahkan serta menjauhkan bahkan mengisolasi masyarakat yang berkonflik. Sementara itu, positive peace lebih pada suasana batin yang bercirikan pada promosi HAM, kesejahteraan, kebebasan dan keadilan sosial. Tanpa itu, kedamaian yang hakiki tidak akan pernah terjadi di dalam masyarakat. Diagram berikut menggambarkan dua sisi rasa damai (peace) dengan segala ciri dan karakteristiknya, dan sisi kekerasan (violence) dengan segala fenomena yang mengiringinya, sebagaimana yang dikutip oleh Wahyudin dalam http://www.un.org/cyberschoolbus/ peace/frame $2 . \mathrm{htm}^{40}$

\section{Tabel 1}

Dimensi Kedamaian dan Potensi Kekerasan

\begin{tabular}{|l|l|}
\hline VIOLENCE & PEACE \\
\hline (Direct) & (Negative) \\
\hline $\begin{array}{l}\text { Personal: assault, } \\
\text { rape, brutality, } \\
\text { terrorism, murder, } \\
\text { ethnic cleansing. } \\
\text { Institusionsl: war, } \\
\text { state-sponsared } \\
\text { terror, industrial } \\
\text { and institusional } \\
\text { violence } \\
\text { and animal life. }\end{array}$ & \\
\hline (Indirect) & \\
\hline $\begin{array}{l}\text { Structural: sexism } \\
\text { racism, }\end{array}$ & $\begin{array}{l}\text { Presence } \\
\text { wellbeing, of }\end{array}$ \\
\hline
\end{tabular}

${ }^{40}$ Wahyudin dalam Pipih Latifah, peny. Pendidikan Kedamaian (Bandung: PT Remaja Rosdakarya, 2015), 64.

\begin{tabular}{|l|ll|}
\hline discrimination, & justice, & gender \\
poverity, hunger, & equity, & human \\
lack of education & rights & \\
and healt service. & & \\
\hline
\end{tabular}

Pemahaman pendidikan damai juga dideskripsikan secara jelas oleh UNESCO yang menyatakan bahwa:

"Peace education refers to the process of promoting the knowledge, skills, attitudes, and values needed to bring about behavior changes that will enable children, youth, and aduls to prevent conflict and violence, bothover and struktral; to resolve conflictpeacefully; and to create the condition conductive to peace, whether at an intrapersonal, interpersonal, intergroup, national or international level. ${ }^{41}$

Dengan demikian pendidikan perdamaian adalah pola pemikiran dan perilaku manusia yang berproses dalam pembelajaran dan pengalaman kehidupan untuk senantiasa mengutamakan ketenangan, kenyamanan, keamanan, kedamaian, kesejahteraan dan keadilan dalam kehidupan bersama segala mahluk di bumi.

\section{Pendidikan Perdamaian dalam Alkitab}

a. Perjanjian Lama

$$
\text { Kata "perdamaian" dalam }
$$

Perjanjian Lama diambil dari kata "syalom." Kata syalom secara harafiah

\footnotetext{
41 UNESCO, Constution of the United Nations Educational, Scientific and Cultural Organization (London: UNESCO, 1954), 1.
} 
berarti sehat walafiat, utuh, keadaan baik.

Kata ini memiliki arti yang sangat luas, yang nampak dari berbagai terjemahan, yaitu selamat (Kel. 1: 13), persahabatan (Yes. 9:15), jangan kuatir (Hak. 19:20), damai (1 Raj. 5 : 12), kesejahteraan (Mzm. 122:7; Yer. 28;7), damai sejahtera (Yes. $48: 18 ; 57: 19)$.

Kata tersebut selalu dijadikan bahasa simbol dalam relasi yang harmonis antara manusia dengan Allah dan sesamanya. Syalom adalah anugerah Allah dan sekaligus tanggungjawab manusia. Jika syalom terwujud maka tidak akan ada orang-orang yang menderita oleh karena konflik yang mengakibatkan orang-orang harus kehilangan tempat tinggal, terpisah dari sanak saudara, tidak ada pengungsian dan lain sebagainya. Perjanjian Lama memperlihatkan bahwa damai bukan saja menyangkut hal fisik dan psikologis seseorang, tetapi juga kedamaian secara komunal struktural. Damai bukan hanya masalah tidak adanya perang dan tekanan, tetapi juga tentang kesejahteraan, serta terbebas dari ketidakadilan dan pembodohan.

\section{b. Perjanjian Baru}

$$
\text { Kata "pendamaian" atau }
$$

"rekonsiliasi" juga diterjemahkan dari kata benda bahasa Yunani: Katallage, artinya: perubahan, rekonsiliasi atau pendamaian.
Kata ini dijumpai dalam pengertian pendamaian, hanya dalam surat-surat Paulus (Rm. 5:10; II Kor. 5:18-20). Dalam bentuk kata kerja dipakai kata katallagen (didamaikan, band. Rm. 5:10a). Kata kerja katallasso dipakai dalam pendamaian kembali seseorang dengan sesamanya (I Kor. 7:11). Dalam pengertian yang sama dipakai kata diallassomai (Mat. 5:24). Dalam Kol. 1:20,22 dan Ef. 2;16 dipakai apokatallaso dalam pengertian yang sama, yaitu pendamaian dengan sesama. ${ }^{42}$

Dalam praktek kultus Helenis, gagasan ini biasanya dipakai, namun kurang menggambarkan hubungan personal antara Allah dan manusia. Sebaliknya, dalam naskah-naskah Yahudi di luar kanon Alkitab, istilah ini dipakai dalam hubungan personal antara Allah dan umat (band. Ant. 3:315; 6:143; 7:153,295), yang menunjuk kepada perubahan sikap Allah. Allah yang tadinya murka berubah menjadi Allah yang mengasihi (2 Makk. 1:5; 7:33). Peranan Allah sebagai penggagas dan pelaku pelaku pendamaian terdapat juga dalam Efesus. 2:16; Kolose 1;20,22. Memang dalam Roma 5:10 kata kerja yang dipakai adalah bentuk aorist pasif, tetapi bentuk itu menunjukan kepada Allah sebagai

\footnotetext{
${ }^{42}$ Samuel B. Hakh, Damai Itu Meneduhkan: Suatu Tinjauan Teologis Alkitab (Bandung: Jurnal Info Media, 2006), 5; band. Colin Brown, The New International Dictionary of New Testament Theology (Grand Rapids, Michigan: Zondervan Publ. House, 1978), 166,167.
} 
pelaku dalam pendamaian. Kata kerja itu menunjuk kepada suatu tindakan yang dengannya damai diwujudkan di antara dua pihak yang berseteru (band. Kej. 7:16). Tindakan itu dilakukan oleh seorang mediator yang tugasnya adalah mengenyahkan kebencian dan membawa orang kepada kedamaian. Jelas bahwa menurut Paulus, pemrakasa sekaligus pelaku pendamaian itu bukan dunia, bukan pula manusia, melainkan Allah. ${ }^{43}$ Kata itu muncul dalam PL 9 kali (Im. 6:30; 16:18,20; Yeh. 45:15,17,20; II Taw. 29:24; Im. 8:15; Dan. 9:24) dalam PB muncul 14 kali. $^{44}$

\section{Isi, Makna, Cakupan, dan Tujuan Pendidikan Perdamaian}

Schmidt dan Friedman (1988) menyatakan, "pendidikan perdamaian bersifat holistik. Pendidikan ini merangkul pertumbuhan fisik, emosi, kecerdasan, dan sosial anak dalam kerangka yang mengakar kuat pada nilai-nilai tradisional manusia. $^{45}$ Di pihak lain, David Hicks mengungkapkan pendidikan perdamaian merupakan kegiatan berantai sebagai aktivitas yang mengembangkan pengetahuan, keterampilan dan sikap untuk menggali konsep perdamaian,

\footnotetext{
${ }^{43}$ Samuel B. Hakh, "Pelayanan Perdamaian Menurut Paulus dan Implikasinya dalam Konteks Indonesia." Orasi Ilmiah STT Jakarta, 2004: 2,5.

${ }^{44}$ Hakh, Damai Itu Meneduhkan, Op. Cit., 6.

${ }^{45}$ Kartadinata Op. Cit., 9.
}

memecahkan rintangan, mengatasi konflik dengan adil dan tanpa kekerasan dan studi yang komprehensif mengenai cara dan pendekatan yang harus ditempuh untuk membina alternatif masa depan yang lebih baik dan berkelanjutan. ${ }^{46}$

Hicks berpendapat bahwa pendidikan perdamaian bertujuan untuk menciptakan kesadaran dalam diri manusia akan pentingnya perdamaian. Siapapun yang belajar tentang pendidikan perdamaian akan sampai pada bagaimana memecahkan persoalan yang disebabkan oleh kekerasan tanpa kekerasan. Senada dengan itu, Harris dan Morisonn mengatakan:

"Social violence and warfare can be described as a form of pathology, a disease. Few people would be satisfied with simply treating the symptoms of a sevelary debilitating or life threatening disease. Yet we continoue to respond to most forms violence and the repeated outbreak of werfare rether than by trying to eliminate their causes".

Menurut Wendel HS (2013), pendidikan perdamaian adalah pendidikan budaya, pengembangan karakter, dan metanoia diri pribadi dan masyarakat sehingga nilai-nilai, seperti: integritas, tenggang rasa, toleransi, saling menghargai, menghormati dan melihat konflik sebagai yang postif dapat diaplikasikan dalam kehidupan sehari-hari.

\footnotetext{
${ }^{46}$ Susan Fountain, Peace Education in UNICEF (New York: United Nations Childer's Fund, Juli 1999). 39.
} 
Pendidikan perdamaian barulah menjadi suatu yang penting dan mendesak setelah terjadi konflik sosial dan poltik atau bahkan agama. ${ }^{47}$ Pendidikan perdamaian haruslah memberikan keterampilan untuk secara aktif menjadi pembuat damai. Siapapun yang telah ikut serta dalam pendidikan perdamaian diharapkan dapat menjadi pembawa damai dan kemudian membagikannya kepada lingkungan sekitar. Sebab salah satu tujuan utama pendidikan perdamaian adalah menyediakan wajah damai, sehingga ketika orang-orang menghadapi konflik akan memilih menyelesaikannya dengan damai. Mereka diajar untuk memahami akar kekerasan yang dapat menghancurkan kehidupan. Namun, pendidikan perdamaian lebih dari sekedar fokus untuk mengatasi, tetapi juga strategi untuk mengembangkan kehidupan masyarakat yang lebih baik.

Dapat ditegaskan bahwa pendidikan perdamaian merupakan proses menfasilitasi perkembangan manusia untuk mengembangkan tata pikir (mindset), sikap dan kecakapan mewujudkan hidup bermutu yang di dalamnya mengandung rongga kehidupan emosi, spiritual, dan kultural yang sehat, memelihara eksistensi kehidupan yang didukung oleh perilaku dan sumber daya

${ }^{47}$ Wahyudin, Op. Cit., 60. yang berkelanjutan, dan menyelesaikan pertentangan yang terjadi dengan menjunjung martabat kemanusiaan. ${ }^{48}$

Tiga konsep UNICEF tentang pendidikan perdamaian ${ }^{49}$ adalah:

1. Pengetahuan yang berdasarkan pendekatan subjek

Pemahaman ini berangkat dari definisi pendidikan perdamaian sebagai sebuah ilmu yang multidisipliner dan pertanyaan moral untuk mengatasi persoalan perang dan ketidakadilan.

2. Keterampilan dan sikap

Pemahaman ini berangkat dari definisi pendidikan perdamaian sebagai sebuah bentuk global yang digunakan untuk semua pendidikan. Peserta didik belajar bersikap toleran dan empati sebagai sebuah keterampilan dalam bekerjasama untuk hidup damai dengan yang lainnya.

3. Mengintegrasikan ketiganya; pengetahuan, sikap dan keterampilan Menurut Saefudin Amsa, pendidikan perdamaian mutlak diperlukan untuk menciptakan ruang bagi individu untuk mengembangkan karakter dan kepribadian yang senantiasa menciptakan harmoni dan kedamaian

\footnotetext{
${ }^{48}$ Kartadinata, Op. Cit., 12.

${ }^{49}$ Feriningsih B.P. Hagni, "Pendidikan Perdamaian Melalui Pendekatan Tradisi Hikmat." Tesis M.Th., STT Jakarta, 2011: 30.
} 
dalam lingkungannya. Pendidikan perdamaian bukan semata-mata proses yang mengajarkan pengetahuan atau keterampilan, misalnya teori perdamaian atau keterampilan negosiasi atau mediasi konflik, tetapi lebih sebagai upaya mengembangkan pola pikir dan kesadaran individu terhadap nilai-nilai keutamaan dalam kehidupan, individu yang memiliki karakter yang penuh kasih sayang, menunjung keadilan dan kesetaraan terhadap sesama. Pernyataan Amsa itu menjadi esensi yang sangat penting manakala pendidikan perdamaian dilihat sebagai ilmu yang hanya mengajarkan tentang mengelola konflik. Hakikat pendidikan perdamaian itu sendiri adalah menerapkan nilai-nilai perdamaian dalam kehidupan naradidik. Melalui nilai-nilai itulah naradidik diharapkan dapat hidup dan mengembangkan nilai-nilai tersebut dalam bermasyarakat. ${ }^{50}$

Proses pengajaran dalam pendidikan perdamaian yang melibatkan semua konsep dimensi; kognitif, afektif, dan psikomotorik di mana ketiga ranah

${ }^{50}$ Hagni, Op. Cit., 31. tersebut saling terkait satu sama lain, dapat dilihat pada gambar berikut: ${ }^{51}$

\section{Tabel 2}

Konsep dan Dimensi Pendidikan Perdamaian

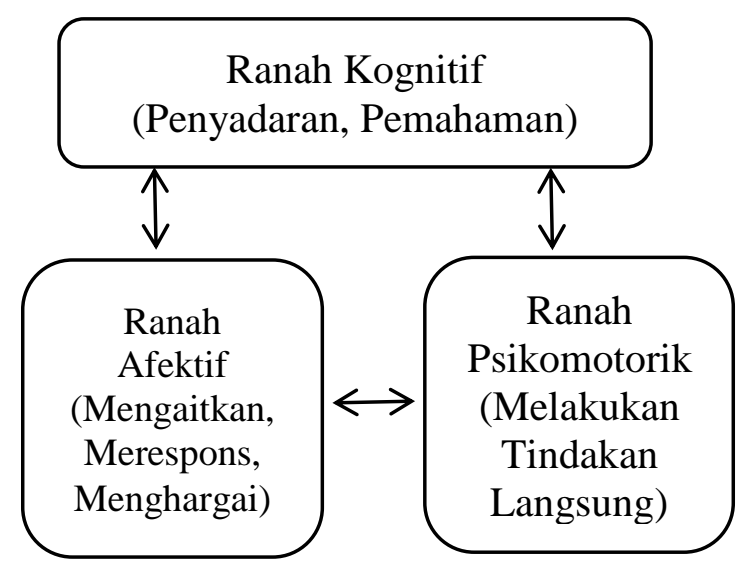

\section{Metode Pendidikan Perdamaian}

Dalam laporan UNESCO, pendidikan perdamaian bisa berlangsung pada jenjang: (1) individu atau pengembangan diri, (2) sekolah atau komunitas, (3) nasional, dan (4) global. Keterampilan dalam menyelesaikan konflik tanpa kekerasan harus dikembangkan oleh setiap anak dalam keluarga. Orangtua harus mempraktikkan cara-cara yang demokratis dengan melibatkan anggota keluarga dalam memikirkan dan membuat keputusan. Negosiasi dalam mencari resolusi sangat dibutuhkan dalam menghindari hukuman fisik. Semangat yang sama juga diberlakukan di sekolah atau komunitas

\footnotetext{
${ }^{51}$ Ahmad Nurcholish, Peace Education \& Pendidikan Perdamaian Gus Dur (Jakarta: Elex Media Komputindo, 2015), 122.
} 
yang tidak hanya terwujud pada tingkat kognitif, tetapi juga pada tingkat pemikiran yang lebih tinggi, seperti menerapkan, menganalisis, mensintesis, mengevaluasi dan menciptakan.

Menurut Johnson, program pendidikan perdamaian yang efektif dapat diciptakan dengan melibatkan lima langkah. Pertama, sistem pendidikan umum wajib untuk dibangun, di mana siswa berinteraksi dan memiliki kesempatan untuk membangun hubungan baik. Kedua, pengalaman bekerja sama harus terjadi dengan mengedepankan tujuan bersama. Ketiga, siswa harus diajarkan mengaplikasikan prosedur kontroversi-kontroversi untuk menjamin bahwa mereka tahu membuat keputusan sulit dan terlibat dalam wacana politik. Keempat, siswa harus diajarkan untuk terlibat dalam negosiasi terpadu dan melakukan mediasi sejawat untuk menuntaskan konflik kepentingan secara konstruktif. Kelima, nilai-nilai sipil harus ditumbuhkan dan mengarahkan siswa pada kebaikan umum masyarakat untuk jangka panjang. ${ }^{52}$

Latihan dan simulasi ini penting diberikan kepada siswa dalam suasana simulasi di kelas dalam bentuk cooperative learning sebagai landasan bagi kegiatan

\footnotetext{
${ }^{52}$ Kartadinata, Op. Cit., 11-12.
}

pendidikan perdamaian. ${ }^{53}$ Dalam dimensi lain, Pela Newsletter, menggarisbawahi bahwa pendidikan untuk perdamaian merupakan sarana penting untuk membangun perdamaian, terutama dari sisi budaya. Hal ini merupakan bagian utama dari pengembangan budaya damai di masyarakat (culture of peace)..$^{54}$

Johan Galtung berpendapat bahwa bentuk pendidikan perdamaian harus seirama dengan ide perdamaian, bukan saja berbicara soal kekerasan, tetapi tentang struktur:

"The method of peace education has to be comatible with idea of peace, it has in itself to exclude not only direct violence, but also struktural violence. This is impertance because schools and universities are still important means of education, and in the structure is the message. $^{55}$

\section{Deskripsi dan Temuan Penelitian}

Penelitian dilakukan dengan pendekatan kualitatif. Metodenya adalah wawancara dan observasi. Setelah melalui kedua tahap dalam metode tersebut, dilakukan triangulasi untuk menemukan data yang benar dan valid.

Penelitian ini mengambil tempat di Kabupaten Poso, Propinsi Sulawesi Tengah, Indonesia. Kabupaten Poso saat

\footnotetext{
${ }^{53}$ Wahyudin, Op. Cit., 59.

${ }^{54}$ Ibid., 68.

${ }^{55}$ Johan Galtung, "Form and Content of Peace

Education." dalam Encyclopedia of Peace

Education, Peny. Charlotte, Monisha Bajaj (NC:

Information Age Publishing, 2008), 49.
} 
ini terdiri dari 19 Kecamatan, 28, Kelurahan dan 142 Desa. ${ }^{56}$

Penelitian difokuskan di tempattempat yang sangat rawan konflik. Persebaran populasi diambil dari tiga wilayah, yaitu Poso Kota Bersaudara, Pesisir Bersaudara dan Lage. Pertama, wilayah Poso Kota Bersaudara meliputi: Kecamatan Poso Kota, yaitu di Kelurahan Lombogia dan Bukit Bambu, Kecamatan Poso Kota Utara di Kelurahan Madale, Kecamatan Poso Kota Selatan di Kelurahan Sayo, Kawua, Ranononcu dan Lembomawo. Kedua, wilayah Pesisir Bersaudara meliputi Kecamatan Poso Pesisir, yaitu di desa Lanto Jaya; Kecamatan Poso Pesisir Utara, yaitu desa Kasiguncu, dan Tangkura; Kecamatan Poso Pesisir Selatan, yaitu di desa Pantango Lemba dan Kalora. Ketiga, wilayah Lage meliputi Kecamatan Lage, yaitu di desa Tagolu, Silanca, dan Sintuwu Lemba.

Data yang diperoleh menunjukkan bahwa jumlah penduduk yang beragama Kristen lebih banyak dibanding agama Islam ataupun agama Hindu dan Buddha. Penduduk beragama Kristen Protestan dan Khatolik berjumlah $73,9 \%$. Jumlah ini dianggap sangat dominan terhadap jumlah agama lainnya.

\footnotetext{
${ }^{56}$ Dinas Kependudukan dan Catatan Sipil Kabupaten Poso, Op. Cit., 1.
}

Akan tetapi bukan berarti jumlah penduduk beragama Islam sangat sedikit di tiga wilayah, yaitu Kecamatan Poso Kota Bersaudara, Kecamatan Poso Pesisir Bersaudara dan Kecamatan Lage. Di ketiga wilayah ini, penduduk beragama Islam lebih banyak jumlahnya. Hanya saja di 15 kelurahan/desa yang diteliti didominasi oleh penduduk beragama Kristen.

Dengan demikian, dapat dikatakan bahwa pergaulan penduduk beragama Kristen di tiga kecamatan besar itu sangat intens dengan mereka yang beragama Islam karena kampung-kampung tetangga di 15 kelurahan/desa yang diteliti adalah kampung-kampung mayoritas beragama Islam.

\section{Hospitalitas}

- Hampir sama dengan pengertian hospitalitas, maka bentuk-bentuk hospitalitas yang ada di Poso adalah seperti sikap ramah, murah senyum, bersahabat, suka bercanda, hangat dan selalu riang dan mau menyapa orang lain ketika bertemu di jalan.

- Saling menghormati dan menghargai, ikut dalam kegiatan kebersamaan seperti lomba desa, dan kesediaan untuk membantu 
orang lain walaupun berbeda suku dan agama.

- Merasa bebas bergaul walaupun masih kuatir dan jaga-jaga diri.

- Bersedia hidup bertetangga dengan mereka yang berbeda suku dan agama. Walaupun pada kenyataannya tempat tinggal penduduk yang beragama Islam dan Kristen selalu terpisah.

- Kesediaan untuk berkunjung pada hari raya agama lain, walaupun hanya pada keluarga-keluarga dekat atau kenalan dekat.

- Kelurahan/desa-desa di Poso mempunyai program hospitalitas yang terstruktur, seperti gotong royong 2 kali seminggu, siskamling/ronda malam dan rapat evaluasi program desa.

- Belum pernah ada pembahasan dengan tema hospitalitas.

- Gereja Kristen sulawesi Tengah (GKST) tidak mempunyai program terstruktur dan terencana yang betemakan hospitalitas.

\section{Sintuwu Maroso}

- Sintuwu maroso mengajarkan seseorang untuk hidup saling mombe tubunaka, yaitu saling menghormati dan menghargai. Dengan mombetubunaka maka kita bisa mencapai sintuwu maroso yaitu persatuan yang kuat.

- Sintuwu maroso terwejawantahkan dalam praktek mosintuwu.

- Sintuwu maroso menghisap dan mengikat orang-orang Poso untuk mengikuti pola kehidupan bersama, yang menyebabkan bahwa orang berjalan bersama-sama, mengambil jalan yang sama, memperhatikan diri dengan seperasaan.

- Gotong royong, hidup saling tolong-menolong, saling menghargai dan terbuka dalam hal berpendapat.

- Saling pengertian, saling menghormati itu mombetubunaka. Siwagi: saling menguatkan, dan malinuwu: saling berbagi dalam kehidupan. Yang kuat berbagi dengan yang lemah. Saling memberi dan menerima.

- Terlibat secara aktif dan sukarela dalam pesta suka dan duka.

- Saling membantu dan berbagi baik materi, waktu ataupun tenaga dalam semua bidang kehidupan. Baik dalam pesta pernikahan, dalam kedukaan ataupun dalam pertanian. Praktek semacam ini dikenal dengan istilah mosintuwu.

- Sintuwu maroso mengikat pasyarakat Poso untuk hidup rukun dan damai. Semua agama, suku dan 
ras diterima dan mempunyai kedudukan yang sama.

\section{Padungku}

- Padungku dari akar kata "dungku" yang artinya sudah selesai; dalam hal ini sudah selesai panen. Jadi, padungku adalah acara adat setelah selesai panen raya oleh masyarakat Poso yang mata pencaharian utamanya adalah bertani.

- Padungku adalah upacara yang terlaksana karena rasa sukur atas usaha/pekerjaan dalamn pertanian yang berhasil.

- Padungku adalah acara jamuan makan yang menyediakan makanan dalam jumlah banyak dan beragam menu serta berlangsung selama sehari penuh.

- Padungku sebagai rasa sukacita atas segala anugerah, kasih dan pendampingan dan penggembalaan serta pemberian Tuhan dalam kehidupan manusia.

- Padung sebagai media pertemuan kerabat-kerabat dekat dan jauh dalam satu jalinan kekerabatan.

- Padungku sebagai media silahturami antar masyarakat di Poso baik Kristen maupun Islam. Padungku mampu menembus sekat dan batas-batas perbedaan suku dan agama.
- Padungku sebagai talk table ala masyarakat Poso. Sebuah pertemuan yang bukan hanya soal makanan, tapi pertemuan untuk berbagi sharing kehidupan. Dapat dikatakan bahwa padungku sebagai media perdamaian.

\section{Pendidikan Perdaamian}

a. Masyarakat Poso sudah merasa aman, tetapi masih sangat waspada. Ada kencenderungan masyarakat masih merasa takut untuk berkunjung ke tempat-tempat dan jam-jam tertentu. Seorang informan berpendapat bahwa rasa cemas dan takut akan baru benar-benar hilang, kalau generasi saat ini yang berusia 17 tahun telah berganti dengan generasi yang baru.

b. Tokoh-tokoh agama (khususnya para pendeta di lingkungan GKST) terus menyuarakan pesan-pesan perdamaian baik melalui khotbah di mimbar-mimbar gereja maupun dalam keseharian.

c. Beberapa LSM tutur berpengaruh terhadap pendidikan perdamaian di Poso, di antaranya LSM Institut Mosintuwu dan Wanana Visi Internasional.

d. Beberapa Gang Pemuda dan remaja berorientasi utuk pendidikan perdamaian di Poso. Nama-nama 
mereka antara lain adalah Moruana, Gang Peace, dan Ongga Bale Peace.

e. Kuatnya dan dominanya peranan militer dalam usaha perdamaian di Poso. Hal tersebut mengurangi pendekatan budaya dalam perdamaian. Meningkatkan operasi Tinombala di Poso. Artinya keberadaan TNI dan Polri akan menjadi program utama dalam penjagaan keamanan di Poso.

\section{Pembahasan/Analisa Temuan Penelitian}

1. Pemahaman dan Pemaknaan Masyarakat Poso Mengenai

\section{Hospitalitas}

Masyarakat Poso memahami hospitalitas sangat terbatas pada hubungan yang menggembirakan, seperti ramah, murah sentum dan menegur dengan santun sesama anggota masyarakat. Hospitalitas seperti itu dijalankan dengan sangat hatihati di Poso. Di sisi lain, ketika hospitalitas dikaitkan dengan penerimaan kepada orang lain, masyarakat Poso memahami bahwa hidup saling menghormati, menghargai dan menerima di Poso juga harus dijalankan dengan sangat hati-hati apalagi dalam kaitannya dengan agama lain. Agama menjadi isu yang sangat sensitif.

\footnotetext{
Hospitalitas di Poso terlaksana karena kebutuhan akan kehidupan.
}

Mungkin terlalu kasar untuk mengatakan bahwa hospitalitas di sana berlangsung dengan basa basi. Tetapi memang pada kenyataannya masyarakat saling bertegur sapa dan ramah kepada sesamanya, hanya karena satu alasan: supaya aman dan damai dan supaya saya tidak mendapat masalah. Bahkan ada indikasi bahwa konflik di Poso dapat berakhir saat ini karena kedua bela pihak yang bertikai sudah lelah berperang, sudah capek berlarian mengungsi dan bersembunyi di hutan. Mereka meletakkan senjata, dendam dan kemarahan bukan karena kesadaran akan arti pentingnya perdamaian, tetapi karena kelelahan berperang. ${ }^{57}$ Walaupun indikasi itu perlu diuji kebenarannya, yang pasti sampai saat ini masyarakat Poso masih menyimpan dendam atas konflik. Dalam keseharian ada kecurigaan yang sangat kepada orang-orang tertentu apalagi orang asing yang beragama tertentu.

Hospitalitas di Poso harus dipahami dan diletakkan pada situasi itu. Hospitalitas yang ada saat ini merupakan hospitalitas para korban, yaitu hospitalitas yang timbul bukan karena kemauan, tetapi karena trauma yang merasuk akibat konflik berdarah terdahulu. Untuk kembali pada hospitalitas yang sejati tidak semudah membalikan telapak tangan. Butuh proses dan adaptasi yang intens. Yang paling

\footnotetext{
${ }^{57}$ J. Santo, Wawancara oleh penulis. Poso (Maliwuko), Indonesia, 29 Mei 2016.
} 
menonjol dalam temuan penelitian tentang hospitalitas di Poso adalah pergaulan dan penerimaan kepada sesama warga secara terbatas. Maksudnya, di dalam pergaulan hidup sehari-hari masyarakat Poso memang sangat ramah dan menerima siapa saja yang mau tinggal dan hidup di Poso. Tetapi, pasca konflik penerimaan kepada orang lain yang 'di luar' komunitas; terjalin dengan sangat hati-hati, waspada dan penuh kejurigaan. Hal ini semakin diperparah dengan kondisi keamanan di Poso yang terkadang kondusif tetapi juga terkadang mencekam. Masih ada kegiatan teroris yang sesekali melakukan aksi teror bom, penculikan, mutilasi dan peperangan di hutan-hutan Poso. Masyarakat Poso khususnya yang bergama Kristen sangat sensitif dan menaruh kecurigaan yang mendalam kepada mereka yang asing. Teroris di Poso adalah pimpinan Santoso, tetapi dengan siapa Santoso bekerjasama, apakah dengan seseorang atau sekelompok orang yang tinggal di dalam atau di luar kota Poso, menjadi kecemasan tersendiri bagi masyarakat Poso yang tinggal di wilayah Poso Kota Bersaudara, Poso Pesisir Bersaudara dan Lage. Orang-orang tertentu yang berpenampilan asing menjadi sasaran kecemasan, tetapi terkadang kecemasan itu tertuju secara sporadis kepada anggota dari penganut agama tertentu di Poso.
Untungnya, masyarakat Poso Kristen hanya terbatas pada rasa cemas/resah/gelisah, waspada, dan curiga tanpa melakukan aksi-aksi reaktif provokatif. Aksi diam/senyap ini ditutupi dengan sikap yang tersenyum ramah dalam bersosialisasi secara terbatas di lingkungannya. Tidak mudah bagi masyarakat Poso untuk segera terbebas dari rasa akan pahitnya sebuah konflik. Tidak mudah untuk melupakan begitu saja rumah yang hancur, harta benda yang lenyap bahkan anggota keluarga yang terbunuh. Berbicara tentang hospitalitas di Poso saat ini tidak akan terlepas dari bayang-bayang duka dan dendam konflik. Karena itu, hospitalitas dalam arti penerimaan kepada orang lain harus diletakkan pada konteks itu. Maksudya, masyarakat Poso saat ini masih ada dalam proses rekonsiliasi baik dengan dirinya sendiri, dengan keberadaannya dan terutama dengan orang lain tersebut. Hal ini berimbas pada bidang kehidupan yang lain, seperti kerukunan, kerjasama/gotong royong, partisipasi pada kegiatan desa/kelurahan dan yang lainnya.

Secara PAK, untuk keluar dari hospitalitas para korban ke hospitalitas sejati, jelas diperlukan proses pendampingan yang panjang baik dalam bentuk mediasi, rekonsiliasi, pastoral dan juga pemberdayaan. Hospitalitas sejati mengajak masyarakat untuk saling 
menerima apa adanya, tanpa permusuhan apalagi dendam. Dibutuhkan kebulatan komitmen untuk menumbuhkan kembali rasa persaudaraan dan persatuan yang pernah ada.

\section{Alkitab Perjanjian Lama} menceritakan beberapa hospitalitas secara unik. Abraham, Lot dan juga Rahab mendapat berkat dan keselamatan karena perbuatan hospitalitas mereka. Abraham mendapat berkat berupa berita mengandungnya Sara istrinya yang sudah uzur, hanya beberapa saat ketika ia menerima dengan tulus orang asing yang melintasi depan rumahnya (Kej. 18:1-8). Demikian juga Lot, ia terselamatkan dari pemusnahan kota Sodom dan Gomora, juga karena bersedia dengan tulus menerima tamu asing untuk tinggal beberapa jam saja di rumahnya (Kej. 19:138). Juga Rahab, ia mendapat berkat tersendiri; walaupun ia berlatar belakang wanita tidak biasa, pada akhirnya ia menjadi satu dari sekian nenek buyut Yesus, juga karena hospitalitas yang luar biasa dia berikan kepada para pengintai yang tidak dikenalnya ketika mengintai kota Yeriko (Yos. 2:1-24).

Hospitalitas janda di Sarfat juga sangat menginspirasi. Di tengah-tengah kegelisahan karena kekurangan bahkan ancaman maut karena kehabisan persediaan bahan makan, tiba-tiba ia kedatangan tamu (1 Raj. 17:7-24). Daerah
Sarfat saat itu kering kerontang karena 2 tahun hujan tidak turun. Janda itu pun mengalami situasi yang sangat kristis. Tidak mungkin baginya untuk menerima orang asing, bahkan memberikan minuman apalagi makan, karena dia sangat membutuhkannya bersama anaknya. Kalimatnya:

"Demi TUHAN, Allahmu, yang hidup, sesungguhnya tidak ada roti padaku sedikitpun, kecuali segenggam tepung dalam tempayan dan sedikit minyak dalam buli-buli. Dan sekarang aku sedang mengumpulkan dua tiga potong kayu api, kemudian aku mau pulang dan mengolahnya bagiku dan bagi anakku, dan setelah kami memakannya, maka kami akan mati."

Hospitalitas Janda di Sarfat mengalahkan kegelisahan batinnya. Dia menanggapi dan melakukan apa yang diminta oleh tamu asingnya. Ia melakukan hospitalitas. Ia menerima tamu asing itu; memberinya makan dan minum, walaupun dia lebih membutuhkan makanan dan minuman itu. Hospitalis perempuan itu disambut Allah melalui nabi Elia sehingga janda di Sarfat bersama anaknya berkelimpahan makanan dan minuman sampai akhir musim kemarau.

"Kemarau panjang" di Poso bisa dianalogikan seperti luka, dendam bahkan duka yang mendalam karena konflik. Sulit melupakan begitu saja. Di saat-saat seperti itulah warga masyarakat di Poso, khususnya yang beragama Kristen dituntut 
untuk berhospitalitas. Sulit, tetapi itulah panggilan imannya. Tidak akan pernah terjadi luka diobati dengan luka, dendam ditutupi dengan dendam, dan duka diakhiri dengan duka. Satu-satunya cara untuk memutusnya adalah menerima kehidupan baru melalui hospitalitas.

Alkitab Perjanjian Baru, khususnya Yesus menunjukan kehidupan baru yang dialami beberapa orang ketika Yesus memberikan hospitalitas-Nya. Perempuan yang kedapatan berzinah (Yoh. 8:2-11), mendapat hospitalitas Yesus walaupun seluruh hukum Yahudi secara sah dan meyakinkan menjatuhkan hukuman mati padanya. Zakheus orang berdosa; pemungut cukai, mendapat hospitalitas Yesus melalui perkunjungan ke rumahnya (Luk. 19:1-10). Hospitalitas Yesus mematahkan seluruh teori dan rumus dunia tentang ketamakan Zakheus. Bahkan walaupun seluruh dunia tidak memberikan hospitalitas kepada Yesus, sebaliknya dengan cinta dan kasih sayang, Ia memberikan nyawa-Nya supaya hopitalitas Allah dan manusia terjalin kembali. Hospitalitas total Yesus membawa kedamaian dan kehidupan kekal. Sebuah rujukan iman yang sempurna.

Rujukan iman seperti itu adalah juga rujukan PAK dalam membelajarkan hospitalitas. Bahwasanya, hospitalitas tidak akan pernah terjadi kalau tidak ada kemauan dari hati yang ikhlas untuk menerima yang 'asing'. Yang asing akan terus menjadi asing, dan pribadi kita pun akan selalu menjadi terasing bahkan terbuang dalam komunitas seperti itu. Artinya, hanya dengan jalan membuka diri kepada yang asing, terciptalah kehidupan bersama.

\section{Cara-Cara Penghayatan dan Pengamalan Budaya Sintuwu Maroso dan Padungku Sebagai Bentuk Tradisi Hospitalitas di Poso}

\section{a. Sintuwu Maroso}

Yang paling menonjol dalam temuan penelitian adalah terpatrinya budaya sintuwu maroso sebagai falsafah kehidupan di sana. Falsafah itu terurai dalam tuwu siwagi, tuwu malinuwu, yaitu hidup saling menguatkan, menopang, menghidupi, menjaga, melindugi, tolong menolong dan saling mencintai untuk mencapai kesejahteraan bersama. Falsafah itu kemudian terwujud dalam posintuwu/mosintuwu yaitu saling memberi dan saling menerima dalam kehidupan bersama. Benang merah yang mengikat semunya adalah mombe tubunaka yang dapat diartikan saling menghargai/menghormati, menuruti tata kesopanan, beretika dan santun.

Pada istilah sintuwu maroso tersirat kata 'kita' di sana (sintuwu kita maroso). Kata 'kita' di situ sama maknanya dengan 
kata 'kita' dalam bahasa Indonesia. Siapa yang dimaksud dengan ' $k i t a '$ di sini? Tentu, tidak lain adalah orang-orang Poso itu sendiri. Kata 'kita' memberi makna bahwa apabila kita secara komunitas bergotong-royong dalam proses bertani, maka panen kita akan berhasil. Dengan itu, kita akan mengalami hidup sejahtera secara bersama-sama pula. Di sini berlaku istilah mosintuwu. Artinya, kalau saya rajin bergotong royong, maka saya akan menerima balasannya. Semakin rajin semakin banyak hasil yang didapat. Kalau saya atau anggota keluarga saya datang pada proses pertanian orang lain, maka orang lain pun akan datang kepada saya. Kebiasaan bergotong royong di ladang, kemudian berimbas untuk bergotong royong membangun desa, membangun jembatan, membangun balai desa, membangun rumah, membiayai secara bersama-sama seseorang atau beberapa orang anak yang sedang studi di kota, dll. yang semuanya mengarah pada kesejahteraan bersama.

Seorang Guru Injil yang pernah bekerja di Poso, dalam pengamatannya terhadap orang-orang Poso, menurutnya mosintuwu ialah 'bercampur gaul dengan baik'. Dalam kata 'sintuwu' ini terdapat paham 'hidup bersama' atas dasar 'kesamaan kehidupan'. Hal ini didasari oleh suatu pola kehidupan bersama yang menyebabkan, bahwa orang berjalan bersama-sama, mengambil jalan yang sama, memperhatikan diri dengan seperasaan. $^{58}$ Sintuwu maroso telah menjadi "frame of reference" di tempat itu. Cara orang Poso bertani adalah cara sintuwu maroso, cara orang Poso membangun desa adalah cara sintuwu maroso, cara orang Poso berpikir dan bertindak adalah cara sintuwu maroso. Kuatnya persekutuan dalam bingkai sintuwu maroso ini mengingatkan kita akan kuatnya persekutuan antar Allah dan manusia.

Borg memberi dan memaknai kata 'bela rasa' secara unik berkaitan dengan persekutuan. $^{59}$ Kata 'bela rasa' lahir dari kata 'compassion' dalam Bahasa Inggris. Sedangkan kata compassion sendiri, berasal dari kata dalam Bahasa Latin: pati dan cum (to suffer with), berarti: deep awareness of suffering of another coupled with the wish to relieve it. Compassion juga bisa diartikan approving a strong feeling of sympathy and a desire to help them. $^{60}$ Dari segi etimologis kata 'compassion' dalam Bahasa Inggris berarti 'merasakan bersama' (passion berarti

\footnotetext{
${ }^{58}$ J. Kruyt, Kabar Keselamatan di Poso.

Terjemahan P.S. Naipospos (Jakarta: BPK Gunung Mulia, 1977), 71.

${ }^{59}$ Marcus J. Borg, Kali Pertama Jumpa Yesus Kembali; Yesus Sejarah dan Hakikat Iman Kristen Masa Kini. terj. Ioanes Rakhmat (Jakarta: BPK Gunung Mulia, 2000), 51.

${ }^{60}$ Robert B. Costello et al. (ed.) The American Heritage College Dictionary 3rd Edition. 1993., 284.
} 
'merasakan' dan awalan com berarti 'bersama'). Jadi, comppassion, bela rasa, berarti merasakan perasaan orang lain dengan cara yang mendalam, merasuk sampai ke organ tubuh dalam dan di bawah kepala, sampai ke hati, paru-paru, perut, jantung, dll. Paling umum bela rasa dikaitkan dengan hal merasakan penderitaan orang lain dan digerakkan oleh penderitaan itu untuk melakukan sesuatu... perasaan bela rasa (compassion) membawa orang pada 'keadaan berbela rasa' (compassionate). Bela rasa lebih menunjukan perasaan atau cara hidup yang lahir dari kemampuan untuk merasakan (penderita) seperti yang orang lain rasakan, ibaratnya seorang perempuan mampu merasakan aktivitas kehidupan janin dalam rahimnya. Perasaan seperti inilah yang disebut perasaan bela rasa (compassion) yang membawa ibu itu pada keadaan berbela rasa (compassionate). Jadi, seperti yang disimpulkan Borg, jika "belas kasih mengenakan suatu wajah insani, [maka] bela rasa suatu hati insani". 61

\section{Berbicara tentang Allah yang} berbela rasa berarti berbicara tentang Allah yang turut merasakan perasaan atau situasi (penderitaan) manusia yang mendorong Allah untuk menyatakan bela rasa-Nya dalam suatu keadaan yang berbela rasa. Bela rasa itu Ia nyatakan dalam dan

\footnotetext{
${ }^{61}$ Borg, Op. Cit., 53.
}

melalui peristiwa historis di mana Allah menjadi manusia, mati sebagai wakil dari mereka yang menderita, miskin, lemah dan tertindas.

Ia mengosongkan diri-Nya dan mengambil rupa seorang hamba, dan menjadi sama dengan manusia (Fil. 2:7). Harus dikatakan bahwa kematian dan kebangkitan-Nya tidak dapat dibayangkan lepas dari penjelmaan-Nya yang merupakan wujud solidaritas/bela rasa Allah dengan manusia yang berdosa. Dengan kata lain, Yesus menjadi sama, senasib, bersetiakawanan atau solider dengan manusia yang berdosa dan malang, sehingga manusia yang berdosa dan malang itu dapat ikut serta dalam kemuliaan Kristus. Yesus mati karena dosa-dosa kita (I Kor.15:3). Ia menjadi kutuk (Gal.3:13). Ia menjadi dosa bagi kita, meskipun Ia sendiri tidak mengenal dosa (2 Kor.5:21). Karena Ia mati untuk seluruh umat manusia, maka ia juga bangkit untuk seluruh manusia. Dan itu berarti zona kehidupan kekal bersama Allah terbuka.

Berdasarkan bela rasa yang seperti itu dapatlah dipahami jika Eckardt mengatakan bahwa penderitaan manusia tidak dapat dipahami sebagai semacam perkara "yang bernilai" atau "yang berharga" (seperti halnya mati syahid). Satu-satunya hal yang dapat dibenarkan sehubungan dengan penderitaan adalah 
mengutukinya dan bekerja keras untuk melenyapkannya. ${ }^{62}$

Itulah yang dilakukan Yesus. Kehadiran Yesus merupakan posintuwu yang besar bagi manusia. Posintuwu dalam bahasa Poso berarti pemberian dalam bentuk uang, beras atau benda lainnya yang menyatakan bahwa dia sintuwu (bersatu/setuju) menopang sebuah kegiatan bersama. Dengan mosintuwu seseorang menyatakan dirinya berbela rasa dengan orang lain. Posintuwu yang diberikan oleh Yesus bukan sebagai pebolosi (mengganti) atas perabe (kredit [perbuatan yang dengannya seseorang wajib menggantinya]) manusia. Tetapi merupakan pemberian/pengorbanan Allah terhadap manusia. Tidak berlebihan untuk mengatakan bahwa keselamatan manusia adalah sintuwu maroso antar anugerah Allah dan tindakan manusia sebagai respon.

Kitab Yakobus 2:14-26 menjadi acuan dalam hal ini. Tulisan Yakobus pada bagian itu dimulai dengan kata "apa gunanya". Artinya tidak ada untungnya, tidak ada faedanya dan tidak ada fungsinya, tidak ada artinya bila seseorang mengaku percaya tapi tidak melakukan tindakan percayanya itu dalam perbuatannya. Yakobus menjelaskan

\footnotetext{
${ }^{62}$ A. Roy Eckardt, Menggali Ulang Yesus Sejarah; Kristologi Masa Kini, terj. Ioanes Rakhmat (Jakarta: BPK Gunung Mulia, 2000), 158.
}

bahwa bahwa jika iman tidak diwujudkan dalam perbuatan, itu bukan iman yang menyelamatkan, dan karena itu tidak berguna. Bagi Yakobus, iman harus disertai oleh perbuatan; yang satu tidak dapat ada tanpa yang lain, sebab iman tanpa perbuatan adalah mati. Intinya orang percaya harus melakukan hal-hal yang baik untuk membuktikan bahwa ia beriman kepada Allah. Beriman adalah tindakan percaya, dan perbuatan adalah juga tindakan percaya. Hal ini nampak dari uraian Yakobus tentang iman Abraham (Yak.2:23). Abraham beriman tapi juga melakukan imannya itu. Demikian juga Rahab. Iman yang tidak nampak dalam perbuatan adalah iman yang kosong, yaitu iman yang tidak bekerja, tidak perpengaruh dan iman yang tidak menghasilkan. ${ }^{63}$

Untuk konteks Poso, sintuwu maroso selayaknya menjadi acuan yang tegas untuk membangun kembali Tana Poso dari puing-puing kehancuran. Orangorang Poso siapa pun dia yang sudah terhisab dalam budaya sintuwu maroso harus menghancurkan perpecahan lalu menggantinya dengan persekutuan. Budaya jangan hanya dijadikan kebiasaan ataupun kebanggaan, tapi budaya harus membawa makna dan perubahan untuk

\footnotetext{
${ }^{63}$ M.K. Sembiring (ed.), Pedoman Penafsiran Alkitab; Surat Yakobus (Jakarta: LAI-Yayasan Karunia Bakti Budaya Indonesia, 2009), 77-85.
} 
mendukung kehidupan dan kemanusiaan.

Budaya tanpa arti dan makna, apalagi jika bersifat menekan adalah budaya penindasan.

Seorang pemikir PAK, Robert W. Pazmino, menjelaskan bahwa PAK tidak bisa terlepas dari fondasi sosiologis. Dalam fondasi yang demikian konstruksi sosial dari realitas budaya harus dipertimbangkan. Mengutip beberapa pakar pendidik, Pazmino berkata:

"Tugas pendidik adalah membuat pengajaran mereka tetap update dan relevan dengan konteks budaya mereka supaya bisa terus memberi dampak pada peserta didik yang hidup dalam budaya tersebut. Bagi pendidik Kristen tugas ini mengharuskan mereka menggunakan pendekatan dan mempertimbangkan perkembangan penelitian dan trend baru. Juga dibutuhkan adanya analisis kritis dan cermat terhadap semua konteks budaya sebelum membuat sebuah agenda pendidikan.... Lalu bagaimana budaya bekerja dalam hidup orang Kristen dan dalam praktik pengajaran mereka? Budaya bagi orang Kristen dapat menjadi gaya hidup kudus yang diekspresikan melalui kejujuran, keadilan dan kebenaran. Budaya bisa menjadi keikutsertaan dalam pekerjaan dunia, membuat atau mengubah suatu hal, dan melakukan hal tersebut dalam rangka menyatakan dirinya sebagai penyandang citra Allah sesuai dengan kehendak dan tujuan Allah yang khusus". ${ }^{64}$

Secara Kristiani, ketika budaya

tidak menjadikan manusia semakin baik dan bermartabat, budaya seperti itu bertentangan dengan Injil. Artinya, budaya itu harus ditinggalkan. Inilah yang dimaksud oleh Neiburh ketika mengatakan

\footnotetext{
${ }^{64}$ Pazmino, Robert W. Fondasi Pendidikan Kristen (Jakarta: BPK Gunung Mulia, 2012), 231-233.
}

bahwa setiap budaya harus ditransformasi. Adapun unsur-unsur transformasi kebudayaan adalah nilai-nilai budaya, adat istiadat masyarakat, pandangan mengenai hidup serta berbagai konsep hidup lainnya yang ada dalam masyarakat. Berbagai kebiasaan sosial, sikap dan peranan yang diperlukan, tingka laku termasuk proses fisiologi, refleks dan gerak atau reaksireaksi tertentu. Transformasi budaya bukan hanya merupakan pengalihan pengetahuan dan ketrampilan, melainkan juga meliputi pengalihan nilai-nilai budaya dan norma-norma sosial. ${ }^{65}$

Penulis beberapa buku PAK, Thomas H. Groome menilai bahwa itulah kepentingan PAK, dalam konteks ini, yaitu membawa nilai-nilai budaya ke panggung kehidupan lalu mengajarkannya dalam konteks iman Kristen yang Alkitabiah. Berkaitan dengan itu, pendapat Groome dapat dianalogikan dalam transformasi budaya seperti pendapat Neiburh di atas. Menurut Groome hasil belajar PAK seharusnya tidak terpusat hanya pada kemampuan kognitif melainkan lebih jauh dari itu, mampu membentuk seseorang menjadi manusia utuh yang manusiawi, mengubah cara berpikir, cara bertindak maupun seluruh sikap hidup atau tindakan hidup manusia. Praksis bukan sekedar

\footnotetext{
${ }^{65}$ Suryana \& Rusdiana, Pendidikan Multikultural: Suatu Upaya Penguatan Jati Diri Bangsa (Bandung: Pustaka Setia, 2015), 88.
} 
bicara tindakan atau aksi melainkan praktik kehidupan yang melibatkan ranah kognitif, afektif maupun psikomotorik. Misalnya, ketika belajar mengenai korupsi, peserta didik tidak saja belajar definisi korupsi atau akibat korupsi, tetapi juga bagaimana cara memberantas dan menghindari korupsi dan tidak menjadi orang yang korupsi. ${ }^{66}$

Dianalogikan dengan sintuwu maroso, berarti sebaiknya peserta didik bukan hanya belajar tentang definisi dan bentuk-bentuk sintuwu maroso, tetapi apa makna dan bagaimana makna itu menjadi berguna. Jadi, ada epistemologi tetapi juga ontologi, proses ilmiah tetapi juga menyentuh hakekat terdalam dari kehidupan. Melalui PAK, peserta didik "bertransformasi menjadi" manusia baru" yang mewujud dalam tindakan hidup.

\section{b. Padungku}

Padungku merupakan tradisi yang hanya dilakukan oleh masyarakat Kristen Poso. Tradisi ini merupakan simbol ucapan syukur anggota Jemaat Gereja atas pemeliharaan dan berkat Tuhan, setelah mereka selesai panen. Awalnya tradisi itu hanya berlaku dari dan oleh komunitas Kristen saja. Maksudnya, padungku terlaksana karena dipicu oleh iman orang-

\footnotetext{
${ }^{66}$ Thomas H. Groome, Christian Religious Education - Pendidikan Agama Kristen (Jakarta: BPK Gunung Mulia, 2010), 181.
}

orang Kristen yang percaya bahwa pertanian mereka berhasil karena telah dijaga, dilindungi dan berkati oleh Allah dalam Yesus Kristus. Iman yang subjektif ini pada awalnya hanya merangkul orangorang Kristen saja. Artinya, padungku hanya berlangsung di antara sesama warga Jemaat. Di sinilah uniknya. Padungku yang tadinya hanya untuk masyarakat Kristen justru kini terbuka untuk semua komunitas dan agama di Poso. Semua orang dari berbagai suku boleh datang dan akan diterima dengan hangat. Baik orang Bugis, Tiong Hoa, Arab, Batak, dll., semuanya boleh datang mengunjungi desa yang melakukan (tuan rumah) padungku. Ziarah dalam padungku mempertemukan orang-orang kota untuk bersilaturahmi dengan orang-orang desa.

Padungku bersifat terbuka. Tidak perlu ada surat undangan. Ketika terdengar padungku akan dilaksanakan di sebuh tempat, pada saat itu juga seseorang merasa terundang. Tidak ada pembatasan tujuan (destination) tempat perkunjungan di hari padungku dan tidak ada juga batasan jam berkunjung. Siapa saja boleh berkunjung di rumah siapa pun. Baik orang yang dikenal maupun tidak. Sebaliknya, tuan/nyonya rumah padungku juga tidak akan menolak orang asing sekalipun yang datang di rumahnya. Hospitalitasnya berlaku sama dengan tamu yang dikenalnya. 
Temuan penelitian menunjukan bahwa padungku dewasa ini dijadikan perjalanan wisata oleh para pengunjung di mana mereka bisa berjalan-jalan menikmati hari yang ramai. Tidak perlu mempersiapkan ataupun membawa uang untuk perbekalan dalam perjalanan wisata itu karena setiap tempat tujuan (destinasi) sudah menyediakannya secara cuma-cuma. Sebagaimana layaknya perjalanan wisata; suasana gembira, damai dan bahagia menjadi bahagiannya. Tidak perlu takut ataupun cemas kerena perbedaan latar belakang agama, suku dan etnis, karena di meja makan padungku semuanya tidak dipertanyakan dan dipersoalkan.

Temuan penelitian yang bermakna lebih mendalam adalah terjadinya rasa persaudaraan dalam damai pada hari padungku, yaitu bertemunya orang-orang yang saling kenal bahkan yang tidak saling kenal di meja makan padungku. Padungku bukan saja mengenai acara makan-makan, tetapi juga media silahturahmi berbagai lintas golongan, suku, ras dan agama di Poso. Padungku merupakan media tempat berkumpulnya orang-orang Poso dari berbagai latar belakang kehidupan. Padungku menyediakan ruang dan waktu bagi yang berbeda latar belakang untuk satu dalam meja perjamuan. Di dalam meja padungku semua orang; baik kaya atau miskin terlayani dengan makanan dan minuman yang sama dan menjadi hidup.
Selanjutnya, padungku memberi tempat kepada yang berbeda untuk membicarakan tema-tema kehidupan sebagai issu bersama. Dialog tentang kehidupan pun terjadi secara alami. Itulah alasan mengapa padungku sangat berdampak bagi perdamaian di Poso.

Meja makan adalah simbol hospitalitas yang hangat dan cara seperti itu menjadi suatu undangan. Meja makan bersifat inklusif. Meja makan merupakan tempat alami untuk berbagi, bercakapcakap dan bersekutu. Percakapan mendalam terjadi saat makan daripada di dalam rapat atau pertemuan formal dan resmi. Persahabatan diperdalam dan solidaritas ditempa. Meja makan senantiasa menjadi simbol rekonsiliasi dan perdamaian. Persahabatan yang kecut, tawar dan dingin dihangatkan dengan cara makan bersama. Meja makan merepresentasikan visi, harapan dan mimpi. Harapan diungkapkan bahwa mereka yang ada disekeliling meja makan itu akan diikat bersama mejadi satu keluarga atau suatu komunitas. ${ }^{67}$

Kita semua menyukai jamuan makan yang lezat dan melimpah. Sebuah padungku (baca: perjamuan) memainkan peranan penting dalam mengikat perjanjian antara Allah dengan umat-Nya. Dalam Keluaran 24:1-11, perjanjian Sinai diikat

\footnotetext{
${ }^{67}$ Antone, Op. Cit., 99-102.
} 
dengan darah dan sebuah jamuan di hadapan Allah. Musa dan para pemuka Israel "...memandang Allah lalu makan" (Kel. 24:11b). Perjamuan ini merayakan perjanjian dan persahabatan antar umat dan dengan Allah sendiri. Dalam Injil, Yesus mopadungku (baca: makan) bersama dengan berbagai orang. Bagi Yesus, sebuah perjamuan lebih dari sekedar mengisi perut seseorang. Sebuah perjamuan adalah saat atau kesempatan untuk mengajarkan kasih yang Allah berikan kepada setiap orang, khususnya bagi mereka yang sangat membutuhkan pesan Allah. Perjamuan Yesus bersama orang miskin, orang-orang berdosa, dan orang-orang yang terpinggirkan merupakan tanda solidaritas dengan mereka yang ditolak dan dianggap hina. Perjamuan-perjamuan ini merupakan lambang perjamuan di Sorga kelak, dan menggambarkan seperti apa perjamuan dalam Kerajaan Allah. ${ }^{68}$

Perjamuan persahabatan Yesus dengan para pengikut-Nya merupakan unsur penting dalam pelayanan publik-Nya dan, menurut Injil, makan bersama dengan pemungut cukai dan para pendosa menandai dimulainya era baru. Ia memasukkan perjamuan persahabatan-Nya sebagai simbol padungku (baca:

\footnotetext{
${ }^{68}$ Arthur E. Zonnoni, Jesus of The Gospel: Apa Kata Injil tentang Dia (Jakarta: Penerbit Obor, 2004), 109-111.
}

perjamuan) abadi di Sorga ${ }^{69}$ Sikap Yesus yang berani menerima undangan untuk makan bersama para pendosa dan orangorang yang terpinggirkan merupakan kejutan sekaligus merupakan undangan keterbukaan tangan Allah bagi semua orang termasuk bukan Yahudi ke dalam kerajan-Nya. ${ }^{70}$ Persis seperti padungku di Poso. Padungku melintasi ras dan agama. Semua orang diterima secara terbuka; baik orang yang dikenal maupun orang yang tidak dikenal. Karena itu, pada hari padungku disediakan makanan bagi orangorang non-lokal. Makanan itu disebut pangkoni atau mompali (makanan bagi orang berpantang terhadap daging babi dan anjing), tetapi itu tidak menghilangkan makna persatuan dan kebersamaan dalam padungku itu.

Dalam konteks Yesus, apapun yang diharapkan oleh para tamu dari sebuah perjamuan, mereka menemukan bahwa Yesuslah yang memberikannya, pada tingkat yang lebih dalam. Bagi yang lapar, Yesus menjadi makanan yang memulihkan, memperbaharui, dan memberikan hidup. Bagi yang haus, Yesus menjadi minuman yang sesungguhnya. Bagi para pendosa, Yesus menjadi pembawa pengampunan. Dapat kita katakan bahwa pada setiap perjamuan makan bersama Yesus mengungkapkan

\footnotetext{
${ }^{69}$ Ibid., 112.

${ }^{70}$ Ibid., 114.
} 
dan merayakan keselamatan yang datang dari Allah ${ }^{71}$

Di dalam padungku, orang-orang Poso berkorban banyak di antaranya tenaga, uang, dan binatang-binatang piaraan; babi, ajing dan ayam yang telah berjasa dalam proses berladang. Pemberian korban ini diyakini akan menjauhkan dari malapetaka dan sekaligus sebagai korban tebusan atas kesalahan-kesalahan selama proses bertani. Secara Kristiani, akibat langsung dari kematian Yesus dan perjanjian dengan Allah adalah pengampunan dosa, seperti kurban di Kenisah menebus dosa-dosa, dan Anak Domba Paskah menyelamatkan orang Israel. Kalau Paskah Yahudi dimengerti sebagai perayaan pengharapan akan pembebasan akhir seluruh umat manusia dari segala macam perbudakan, maka Perjuamuan Kudus Kristen juga merayakan pengharapan yang sama. Ini merupakan pengharapan yang terusmenerus dan berkesinambungan; pengharapan akan pembebasan dari kematian, pengharapan akan persekutuan dengan Allah. Pemberian diri Yesus, menyelamatkan orang-orang yang berdosa serta memberikan pengampunan kepada mereka. ${ }^{72}$ Sasaran utama perjamuan terakhir ini tercapai ketika Yesus dengan khidmat mengambil roti dan anggur,

\footnotetext{
${ }^{71}$ Ibid., 116-117.

${ }^{72}$ Ibid., 122.
}

kemudian menawarkannya kepada muridmurid dalam suatu gerak isyarat yang sejak itu menjadi bagian terpenting dalam ibadah Kristen. Yesus memecahkan roti, dan memberikannya kepada mereka sebagai tubuh-Nya, "yang diserahkan untuk kalian"; Ia menawarkan anggur kepada mereka sebagai "darahku yang mensahkan perjanjian Allah, darah yang dicurahkan bagi orang banyak'. Dia memesan agar mereka selalu melakukannya "untuk mengenang Aku". 73

Makan bersama yang melintasi ras, agama dan suku dalam perayaan padungku yang dilakukan setiap tahun di Poso sudah saatnya dipahami sebagai proklamasi bahwa perdamaian telah melewati masa penindasan dan perbudakan dalam kerusuhan. Padungku itu merupakan perdamaian yang selalu diulang tahun demi tahun, sebagaimana orang Kristen setiap kali datang ke meja Perjamuan Kudus; serta mengenang kembali pendamaian yang dilakukan oleh Yesus Kristus. Praktik percakapan di meja makan Yesus secara erat dikaitkan dengan penyembuhan dan rekonsiliasi di seluruh kehidupan dan pelayanan Yesus. Percakapan meja makan dengan orang asing dan komunitas luar jelas merupakan tindakan rekonsiliasi - berpindah dari

\footnotetext{
${ }^{73}$ R.T. France, Yesus Sang Radikal; Potret Manusia yang Disalibkan (Jakarta: BPK Gunung Mulia, 2000), 130.
} 
orang asing menjadi sesama dan teman seperti yang dipraktikkan Yesus ketika Ia makan bersama dengan pemungut cukai dan pesta di waktu puasa (Mark. 2:16; Luk. 7:34). Yesus juga mengajarkan tentang komunitas Kerajaan Allah melalui cerita tentang meja makan. Salah satunya adalah pesta besar dibuat oleh seorang bapak karena anaknya yang hilang telah kembali (Luk. 15:11-32). Pesta lain adalah pesta terbuka untuk semua orang di jalanan ketika semua tamu yang diundang tidak mau datang. Ini memperlihatkan bahwa di meja Allah, semua orang disambut karena setiap manusia adalah anak-anak Allah, bahkan walaupun tidak setiap orang mau datang untuk menggenapi dengan gembira. $^{74}$

Contoh-contoh percakapan di meja makan ini merupakan ilustrasi dari tindakan dan hakikat Allah sebagai Pencipta yang penuh kasih dan rahmani begitu ramah dan terbuka, sehingga tidak ada seorang pun yang dikecualikan. Gambaran ini sangat berkaitan dengan kebutuhan manusia untuk saling memahami, saling menghormati, dan saling terbuka, khususnya di masyarakat majemuk. Ini bisa dipakai secara harafiah ataupun kiasan, konsep meja makan senantiasa berkonotasi hospitalitas yang

\footnotetext{
${ }^{74}$ Antone Ibid., 105-107.
}

melimpah, keterbukaan sejati, dan perayaan sukacita bersama. ${ }^{75}$

Tradisi hospitalitas di dalam budaya sintuwu maroso dan padungku sangat kental di Poso. Budaya sintuwu maroso umpamanya. Budaya ini sudah hidup di Poso sejak nenek moyang orang Poso hidup. Budaya itu menekankan pada kuatnya persatuan yang bercirikan hidup saling menguatkan (tuwu siwagi) dan hidup saling menghidupi (tuwu malinuwu). Hidup saling menguatkan artinya saling menopang, saling mendorong, saling bahumembahu, saling mempedulikan/merasakan bersama-sama (empati) dan bekerja bersama-sama (gotong royong) untuk menciptakan kehidupan yang sejahtera secara bersamasama. Hampir sama dengan itu, tuwu siwagi (saling menghidupi), artinya saling memberi dan menerima, tolong-menolong, serta saling mengasihi.

Dalam budaya sintuwu maroso yang bercirikan tuwu siwagi dan tuwu malinuwu itu orang-orang Poso diikat oleh sikap mombe tubunaka, yaitu saling menghargai. Maksudnya, orang-orang Poso disadarkan bahwa persatuan yang kuat (sintuwu maroso) tidak akan terbangun kalau anggotanya tidak hidup saling menghargai, yakni menghargai baik soal pendapat dan pemberian orang lain,

${ }^{75}$ Antone, Op. Cit., 115-116. 
termasuk saling menghargai antar yang kuat dan lemah, kaya dan miskin, bahkan saling menghargai antar agama, suku dan ras yang berbeda. Hidup saling menghargai (mombe tubunaka) itulah yang menghangatkan dan melanggengkan budaya sintuwu maroso di Poso.

\section{Budaya sintuwu maroso} terejawantahkan dalam praktek mosintuwu yang bisa diartikan keterlibat dalam persetujuan, keterlibatan dalam kehidupan, ikut serta melakukan atau bekerja bersama-sama. Mosintuwu bisa berupa materi, tenaga/waktu ataupun pemikiran. Bentuk mosintuwu yang paling dominan di Poso adalah ketiga-tiganya, yaitu memberikan materi, tenaga/waktu dan pemikiran. Jadi, dalam budaya sintuwu maroso, orang-orang Poso mengambil pola kehidupan bersama yang menyebabkan orang berjalan bersama-sama, mengambil jalan yang sama, dan memperhatikan diri dengan seperasaan. Karena itu, tidak berlebihan untuk mengatakan bahwa sintuwu maroso yang dipahami orang Poso menyangkut totalitas hidup mereka.

Tradisi hospitalitas lainnya dalam budaya Poso adalah padungku. Padungku pada intinya adalah ucapan syukur tahun jemaat selesai panen. Hal ini dimaklumi karena menjadi petani adalah mata pencaharian utama di Poso. Berkaitan dengan ucapan syukur, maka penghayatan utama dalam perayaan padungku adalah rasa terima kasih kepada Tuhan semesta alam atas segala berkat dan rejeki yang telah diberikan sepanjang tahun, baik di ladang pertanian ataupun di bidang usaha dan pekerjaan lainnya. Penghayatan itu kemudian diamalkan melalui penyediaan dan pemberian makanan kepada anggota keluarga dan tamu sebagai bentuk seremonialnya. Tidak heran kalau acara perayaan padungku identik dengan acara makan-makan. Sepanjang hari akan terus tersedia aneka menu makanan padungku di meja makan. Makan itu disiapkan dengan penuh rasa sukacita, tulus, ikhlas dan penuh kedamaian.

Pada titik ini hospitalitas padungku dapat dirasakan dan dilihat. Ada sebuah kerelaan untuk menyediakan dan memberikan yang terbaik kepada 'Sang Lain' melalui kehadiran 'yang lain' dalam jamuan makan. Dalam perayaan padungku, ada penghayatan dan pengamalan bahwa saya adalah bagian dari 'yang lainnya'. Perayaan padungku tanpa kehadiran 'yang lain' tidak memiliki makna apapun. Sama halnya dengan hospitalitas tanpa penerimaan kepada yang 'asing' juga tidak memiliki makna apapun. 
3. Peran Tradisi Hospitalitas dalam Budaya Sintuwu Maroso dan Padungku untuk Pendidikan Perdamaian dalam Mengatasi Konflik di Poso

Kepercayaan sangat tinggi diberikan kepada TNI dan Polri dalam menyelesaikan konflik di Poso. Karenanya, sudah menjadi pemandangan biasa apabila ada aparat berseragam dan beratribut lengkap berkeliaran di jalanan kota ataupun pedesaan Poso. Kepercayaan publik Poso kepada TNI dan Polri untuk menyelesaikan konflik memang terlihat jelas sejak konflik itu terjadi hingga kini. Bukti yang paling otentik adalah dalam tiga kali pemilihan Bupati Poso, selalu dimenangkan oleh eks TNI atau Polri. Dalam kondisi Poso yang masih rawan konflik saat ini, memang kehadiran unsur TNI dan Polri sangat dibuntuhkan. Tidak ada kabupaten di Indonesia ini yang mana seluruh kelurahan/desanya ditempatkan secara permanen anggota TNI dan Polri. Itu hanya terjadi di Poso. Setiap kelurahan/desa di Poso mendapat 2 orang petugas, yaitu 1 orang TNI Bintara Pembina Desa (Babinsa) dan 1 orang Polisi Masyarakat (Polmas).

Pada dasarnya militer adalah alat yang diciptakan negara untuk menjamin keamanan di negara itu sendiri, tetapi pada kasus daerah berkonflik, ketika militer dengan pendekatan senjata yang menjadi pilihannya, maka cara-cara pendekatan kemasyarakatan dan kearifan lokal akan ditinggalkan. Militer sebenarnya bukan ditugaskan untuk mengawal aktivitas warganya, tetapi menjaga keamanan dari serangan musuh asing. Untuk daerah yang sedang berkonflik militer dibutuhkan bukan untuk meciptakan keamanan, tetapi untuk memediasi mereka yang bertikai. Turunnya militer di daerah yang rawan konflik yang berbau sara, tidak menjamin keamanan dan kenyamanan, karena militer juga terkadang rawan akan kepentingan politik dan keadilan. Belum lagi, kehadiran militer sebagai alat negara terkadang lebih menekankan pada wewenangnya sendiri daripada aspirasi rakyatnya. Negara lebih cenderung mengurangi kebebasan dan kesejahteraan warga demi 'keamanan dan ketertiban" negara.

Secara psikologis kehadiran militer di Poso saat ini membawa keamanan, tetapi bukan kenyamanan. Militer memang dibutuhkan untuk pengejaran kepada Santoso atau anggota teroris lainnya, tapi tidak bisa dipungkiri bahwa pendekatan militer selalu meninggalkan konflik sosial baru. Keamanan yang timbul pun hanya merupakan kemanan yang terselubung. Artinya sepintas terlihat keadaan sudah aman, tetapi itu terjadi hanya karena tekanan; bagai luka yang sembuh di luar tetapi dalamnya tetap menganga. Dampak psikologis lainnya, misalnya anak-anak 
yang terbiasa melihat senjata akan menyimpan itu dalam alam bawah sadarnya.

Perdamaian dapat ditempuh dengan lima cara. Pertama, konsiliasi, yaitu mempertemukan kedua belah pihak untuk membicarakan dan mencari jalan keluar bersama atas masalah yang ada. Kedua, mediasi, yaitu pertemuan antara orang yang bertikai melalui bantuan seseorang atau lembaga lain sebagai perantara. Ketiga, arbitrasi, di mana keputusan perkara atas konflik lebih didominasi oleh hukum atau undang-undang yang diserahkan kepada lembaga tertentu yang berotoritas. Di Poso, hukum harus ditegakkan untuk mereka yang telah sengaja memprovokasi dan terlibat sebagai otak pelaku dalam kerusuhan. Proses hukum yang adil akan menimbulkan kepuasan dan kepercayaan tersendiri dalam usaha perdamaian di sana. Keempat, paksaan, yaitu perdamaian yang dilaksanakan secara terpaksa dengan menggunakan senjata atau kekerasan lain. Kelima, détente, yaitu berupaya berdiplomasi supaya ketegangan bisa diminimalisasi. ${ }^{76}$ Cara pendekatan budaya merupakan percampuran antara pendekatan konsiliasi, mediasi dan detente. Disebut demikian karena budaya pada satu sisi dapat dapat mempertemukan orang-

\footnotetext{
${ }^{76}$ Suryana \& Rusdiana, Op. Cit., 38-39.
}

orang yang bertikai sekaligus menjadi pengantara dengan tujuan untuk meminimalisasi konflik itu sendiri. Menurut Karnavian (Kapolri saat ini) pendekatan budaya tidak kalah penting dalam penyelesaian konflik. Menurutnya peranan budaya sangat dibutuhkan. Kearifan lokal merupakan suatu kekayaan budaya lokal yang mengandung kebijakan hidup, pandang hidup (way of life) yang mengakomodasi kebijakan (wisdom) dan kearifan hidup. $^{77}$

Pendekatan budaya lokal di Poso menjadi sangat penting. Secara khusus pendekatan melalui tradisi sintuwu maroso dan padungku. Kedua budaya ini merupakan warisan tradisi nenek moyang orang Poso secara terun-temurun. Sintuwu maroso merupakan sesuatu yang ada sejak dahulunya dan terpatri dalam hati sanubari setiap orang Poso. Menggunakan pendekatan tradisi sintuwu maroso dan padungku dalam mengatasi konflik Poso, berarti menggunakan hati, jiwa dan pemikiran orang Poso sendiri. Sintuwu maroso umpamanya. Dalam budaya ini semua masyarakat Poso merasa terikat dengannya. Terikat bukan dalam arti menekan, tetapi membebaskan. Maksudnya melalui budaya itu semua orang merasa diterima dan diperlakukan secara sama. Tidak ada batasan dalam

\footnotetext{
${ }^{77}$ Karnavian, Op. Cit., 256-257.
} 
pergaulan. Sekat agama tidak memisahkan seseorang dengan yang lainnya. Perbedaan etnis bukan kendala untuk bertegur sapa. Sintuwu maroso mempersatukan orang Poso. Bahkan sintuwu maroso memberi peluang dan tempat kepada agama dan suku apa saja untuk menetap dan hidup di Poso.

Bagi orang Poso, budaya sintuwu maroso adalah hidupnya. Cara berpikir, cara pandang, cara kerja dan cara bersikapnya adalah cara sintuwu maroso, yaitu cara dalam semangat tuwu siwagi, tuwu malinuwu dengan etos mombetubunaka.

Di dalam mombetubunaka itu ada keterbukaan untuk saling mengakui kesalahan. Mengakui kesalahan menjadi sangat penting dalam proses rekonsiliasi. Rekonsiliasi terjadi jika kedua pihak saling mengakui dan mengampuni kesalahan. Artinya, mombetubunaka mengarah pada sikap rekonsiliasi di mana setiap orang memahami dan memaklumi tentang kejadian kelam di masa lalu. Nilai-nilai dalam budaya sintuwu maroso inilah yang dapat berperan untuk pendidikan perdamaian di Poso. Budaya sintuwu maroso adalah budaya damai.

Demikian juga dalam tradisi padungku. Budaya yang satu ini memang lahir dari dan hanya dilaksanakan oleh masyarakat Kristen Poso. Akan tetapi, perayaan padungku mampu melintasi agama suku dan etnis yang ada di Poso. Bagaimana tidak, melalui padungku orang dari segala tempat di Poso dapat betemu; baik orang dari pegunungan maupun yang tinggal di tepian pantai. Baik agama Islam, Hindu ataupun Kristen, baik lintas etnis di Poso dapat dipertemukan melalui meja makan padungku. Berbicara mengenai meja makan, tentu berbicara mengenai makanan. Akan tetapi padungku yang sesungguhnya bukan saja berbicara mengenai acara makan-makan, tetapi perayaan kehidupan yang dilandasi oleh rasa syukur kepada Tuhan yang telah memberikan kehidupan itu sendiri. Sebagai perayaan kehidupan, padungku yang diawali dengan makan-makan akan berlanjut pada dialog kehidupan. Di sinilah letak peran budaya padungku untuk pendidikan perdamaian di Poso di mana orang-orang 'asing' bertemu satu sama lain, duduk dalam satu lingkaran meja lalu membicarakan issu-issu kehidupan bersama. Padungku dapat mempererat persahabatan yang sudah lama, padungku dapat menghangatkan pertemanan yang dingin, bahkan padungku dapat mencairkan suasana yang tegang. Padungku memberi tempat kepada setiap orang untuk merayakan kehidupannya. Dengan cara demikian benarlah apa yang disebut Pazmino tentang fondasi sosiologis dalam PAK, bahwa walaupun beberapa budaya di dunia bersifat lokal Kristen pada 
awal sejarahnya, justru dalam hal inilah tertanam potensi budaya Kristen di tengah masyarakat yang pluralistik dan multikultural. $^{78}$

Dengan menggunakan tradisi hospitalitas dalam budaya sintuwu maroso dan padungku sebagai sesuatu yang khas Poso, maka dapatlah kita pahami perkataan Freire tentang pendidikan untuk orang tertindas:

"Pendidikan semacam itu harus dilaksanakan dengan, bukan untuk kaum tertindas semata. Karena itu adalah perjuangan tanpa henti untuk meraih kembali kemanusiaan mereka. Pendidian ini membuat penindasan dan penyebabnya menjadi obyek refleksi kaum tertindas, dan dari refleksi itulah lahir pembebasan". ${ }^{79}$

Artinya, pendidikan bagi masyarakat yang mengakami konflik, tidak semata mengutamakan pendekatan dari luar, tetapi juga pendekatan dari dalam, yang melibatkan dirinya, hatinya dan jiwanya secara pribadi karena yang akan berdamai adalah segenap eksistensi pribadinya. Budaya sintuwu maroso dan padungku merupakan sesuatu yang berasal dari dalam, bukan dari luar diri orang Poso; yang dengannya setiap orang merasa terhisab.

Secara Teologis-PAK, perdamaian merupakan kebutuhan sekaligus perintah kepada manusia untuk mengusahakannya.

\footnotetext{
${ }^{78}$ Pazmino, Op. Cit., 233.

${ }^{79}$ Paulo Freire, Pedagogy of the Oppressed (Harmondsworth: Penguin, 1982), 25.
}

Dalam suratnya kepada jemaat di Korintus, Paulus dua kali menegaskan; "Allah... telah mempercayakan pelayanan pendamaian itu kepada kami" (2 Kor. 5:18,19). Artinya, perdamaian yang adalah kebutuhan manusia, tidak akan datang dengan sendirinya tanpa manusia secara aktif mewujudkannya. ${ }^{80}$

Dalam Alkitab; perselisihan dan permusuhan mudah saja terjadi antara saudara kembar Esau dan Yakub (Kej. 25:19-34). Selama mereka tidak mau berdamai, selama itu juga terpelihara kebencian dan ketakutan di antara mereka (Kej. 32:1-21). Tetapi ketika tangan mereka terulur untuk berjabat dan tubuh mereka saling berangkulan, maka pada saat itu juga kebencian dan ketakutan sirna (Kej. 33:1-20).

Dalam kisah itu, tidak dinyatakan secara eksplesit pengampunan dari Esau kepada adiknya Yakub. Namun, dalam gambaran tertentu, pengampunan itu dapat menjadi lebih jujur dan murni jika itu tidak diucapkan saja tetapi diwujudkan dalam tindakan. Esau membuang semua rasa dendam dan kebencian terhadap adiknya. Peluk dan ciuman merupakan wujud dari pengampunan dan tanda cinta kasih di antara dua bersaudara itu. Kebencian dan dendam dibuangnya jauh-jauh dan

\footnotetext{
${ }^{80}$ Hakh, "Pelayanan Perdamaian Menurut Paulus..”, Op. Cit., 15.
} 
rekonsiliasi atau perdamaian dengan saudara tercipta kembali. ${ }^{81}$

Demikian juga dalam kisah hidup Yusuf dan sudara-saudaranya (Kej. 37:136). Walaupun Yusuf dijual oleh saudarasaudaranya dan mengalami penderitaan di negeri asing, tetapi Yusuf mengampuni bahkan melupakan kejahatan saudarasaudaranya. Ketika ia sudah berhasil di Mesir, ia justru memanggil saudarasaudaranya dan ayahnya untuk tinggal dan hidup di sana. Bagi Yusuf apa yang dialaminya di masa lalu adalah bagian dari rencana Tuhan untuk masa depan bersama yang lebih baik. ${ }^{82}$

Daud, dalam Mazmur 133:1-3 menuliskan tentang kehidupan persadaraan yang rukun, demikian:

1. "Sungguh, alangkah baiknya dan indahnya, apabila saudara-saudara diam bersama dengan rukun. Seperti minyak yang baik di atas kepala meleleh ke janggut, yang meleleh ke janggut Harun dan ke leher jubahnya. Seperti embun gunung Hermon yang turun ke atas gunung-gunung Sion. Sebab ke sanalah TUHAN memerintahkan berkat, kehidupan untuk selama-lamanya”.

Mazmur ini secara jelas menuliskan kata "saudara-saudara diam bersama dengan rukun", bukan "saudarasaudara seiman dengan rukun". Artinya, kehidupan yang diharapkan oleh Daud

\footnotetext{
${ }^{81}$ Hakh, Damai Itu Meneduhkan, Op. Cit., 34.

${ }^{82}$ Ibid., 37.
}

adalah kehidupan yang tetap rukun dan damai walaupun mereka berbeda suku (waktu itu Israel ada 12 suku). Itu juga mengungkapkan kebenaran rohani yang sama dengan Yohanes 17:1-26 di mana Yesus berdoa agar para pengikut-Nya ditetapkan dalam kasih, kekudusan, dan persatuan. Ia tahu bahwa Roh Kudus tidak dapat bekerja di antara mereka jikalau ada perpecahan yang disebabkan oleh dosa dan ambisi pribadi (band. 1 Kor 1:10-13; 3:13). Tetapi kasih yang sungguh-sungguh bagi Allah dan sesama, bersamaan dengan penyucian dalam kebenaran firman Allah, akan membuat Allah mendekati dan mengurapi umat-Nya.

Konflik yang sangat kejam yang telah terjadi di Poso meninggalkan duka dan dendam yang mendalam. Tidak ada suku bangsa di dunia ini yang akan mampu membebaskan orang Poso dari duka dan dendamnya. Yang akan mampu melakukannya hanya orang Poso itu sendiri. Artinya, perdamaian di Poso akan datang jika ada pengakuan dan pengampunan dari orang Poso itu sendiri. Semangat kekeluargaan dan persatuan yang merupakan nilai hakiki dari sintuwu maroso dapat menjadi pendorong untuk mengampuni dan berdamai dengan sesama.

Penyusupan kata "kita" secara ekplisit di antara kata sintuwu maroso bisa saja dipahami sebagaimana orang-orang 
Poso memahaminya tempo dulu; berkaitan dengan masalah ekonomi dan politik. "Kalau kita berperang terus, kapan kita akan aman, kalau kita mengungsi terus, kapan panci di dapur kita terisi dengan makanan? Kalau kita tidak menjaga Tana Poso dari gangguan para pengacau, siapa lagi? Karena itu, kita harus bersatu melawan musuh-musuh kita. Musuh kita bukanlah suku-suku dan agama-agama yang berbeda, tetapi penindasan, ketidakadilan dan kekacauan. Sintuwu maroso dan padungku telah mengajarkan bagaimana seharusnya tanda-tanda Kerajaan Allah diusahakan dan dikelola secara bersama.

Groome mengusulkan sebuah teori yang disebutnya berbagi praksis Kristen (share christian prakxis). Menurutnya, tindakan masa kini, yaitu keterlibatan manusia secara utuh di dunia, apa yang sedang kita lakukan secara fisik, emosi, intelektual, dan spiritual dalam hubungan antar personal. Imajinasi bukanlah "lamunan". Imajinasi adalah menuntut orang untuk keluar, imajinasi adalah proses untuk berpikir. Sering dalam proses pendidikan, imajinasi peserta didik ditolak sebagai lamunan yang tidak berarti. Imajinasi membutuhkan pikiran dan perasaan (kognitif dan afektif). Imajinasi di sini adalah keadaan di mana seseorang bermimpi tentang masa depannya dan masa depan bersama. Dalam imajinasi itu ada visi ke depan. Visi Allah bagi ciptaan; visi adalah Kerajaan Allah di mana panggilan dan harapan yang melaluinya kita harus menjalani kehidupan kita. ${ }^{83}$

Masih menurut Groome, dialog juga menjadi penting. Dialog adalah media perjumpaan aku-engkau di mana dua orang atau lebih membagikan dan mendengarkan cerita-cerita dan visi reflektif mereka. Dialog dilakukan dengan kasih, kerendahan hati, saling percaya, pengharapan dan dengan penalaran kritis. Dialog berlangsung secara horisontal dan vertikal. Dialog harus dilakukan dalam susana terbuka, jujur dan saling percaya, Susana yang nyaman tanpa dominasi satu pihak terhadap pihak lain. Dialog yang dimaksudkan berbeda dengan diskusi. Mengapa? Dalam diskusi ada sanggahan dan klarifikasi yang sifatnya menguji, namun dalam dialog, orang akan saling menghargai, mempercayai dan sabar untuk mendengarkan. ${ }^{84}$

Groome melanjutkan, cerita Kristen adalah seluruh tradisi iman dari orang-orang yang diwujudkan dalam kehidupan. Cerita itu berupa berbagai tradisi yang ada dalam Alkitab maupun pengalaman rohani orang beriman di mana Allah hadir dalam sejarah kehidupan mereka. Alkitab bukanlah cerita karangan para penulis, melainkan kesaksian iman di

\footnotetext{
${ }^{83}$ Groome, Op. Cit., 271-275.

${ }^{84}$ Ibid., 275-280.
} 
mana Allah turut bekerja dalam sejarah hidup manusia. Jadi, Alkitab bukan "sekadar cerita". Dari proses tersebut, kemudian tiap orang terpanggil untuk membuat keputusan berdasarkan keyakinan imannya lalu menghasilkan tindakan baru. ${ }^{85}$

Dengan transformasi seperti ini secara otomatis dialog antar agama terjadi, yaitu dialog kehidupan - dialog kemanusiaan. Itu berarti, sintuwu maroso dan padungku akan mengantar dan menempatkan orang-orang Poso - semua suku dan agama - pada rekonsiliasi. Paul F. Knitter mengatakan (dari sudut pandang ekologi) bahwa penderitaan global menuntut tanggung jawab global pula. Tanggung jawab global merupakan dasar bersama bagi dialog antar umat beragama untuk memperjuangkan pembebasan. Dalam upaya menyeimbangkan kepelbagaian religius-kultural dengan tanggungjawab global, menurut penulis, tanggungjawab lebih penting daripada kepelbagaian. Kalau kini orang sedang mencari sesuatu yang bisa menjadi dasar kepercayaan mereka bagi kemungkinan dialog yang otentik dan yang akan mengarahkan upaya mereka dalam kemungkinan ini menjadi kenyataan, penulis berpendapat bahwa mereka dapat menemukannya di sini: suatu

${ }^{85}$ Ibid., 280-282. tanggungjawab global terhadap kesejahteraan manusia dan ekologi. Tanggungjawab ini dapat memberikan motivasi untuk mendorong kebutuhan untuk berdialog yang diakui secara global. Karena keprihatinan semacam itu terhadap soteria telah menciptakan solidaritas secara alamiah dan otomatis, maka keprihatinan tersebut memberikan motivasi dan komitmen terhadap tugas dialog antaragama. Solidaritas ini menghubungkan kosmos, kemanusiaan, dan keilahian dalam suatu mutualitas dan kesalingterhubungan di mana kita semua bertanggungjawab terhadap kesejahteraan satu sama lain. Solidaritas semacam ini hanya dapat diyakini atas dasar percaya kepada Roh universal - atau kepada sesuatu yang memberikan identitas kita, namun menghimpun kita dalam kesatuan, dan memanggil kita untuk saling melayani. Jadi, Roh bukanlah suatu dasar, tetapi suatu kesaling-terhubungan yang memupuk persatuan melalui partikularitas, dalam kasih bersama.

Melaksanakan suatu dialog antaragama yang soteriosentris, yang memiliki tanggungjawab global sebagai konteksnya, titik berangkatnya dan tujuannya adalah mengusulkan suatu dialog di mana praksis memainkan peranan penting. Mitra dialog tidak boleh hanya berbicara tentang tradisi religius mereka masing-masing, tetapi juga tentang bagaimana tradisi itu bisa 
dipahami dan perlu dipahami ulang dalam dunia kontemporer kita. Dialog harus menghubungkan tradisi kita dengan pengalaman kita dan dunia ini. Penderitaan itu universal dan bersifat langsung sehingga menjadi ranah yang sangat cocok, dan diperlukan untuk membangun suatu dasar bersama dalam melaksanakan perjumpaan antar-agama. Oleh karena itu, suara korban yang tersingkir memiliki tempat terhormat dalam dialog, bukan karena mereka begitu berbeda, tetapi karena perbedaan mereka menantang dan bisa merusak atau mengalihkan kesadaran kita.

Agama mengundang hal-hal yang lebih daripada sekadar manusiawi untuk mentransformasi atau membebaskan manusia. Karena pengalaman keagamaan yang berbeda-beda itu muncul dari dalam komitmen yang sama terhadap tanggungjawab global. Upaya mengatasi penderitaan dan ketidakadilan tidak hanya memberikan kepada kita "indra peraba" pengalaman yang dengannya kita bisa memahami bahasa keagamaan, tetapi juga suatu proses eksistensial, yang dalam kepelbagaian wujudnya dapat ditemukan dalam kebanyakan tradisi keagamaan. Pengalaman-pengalaman keagamaan bisa sama untuk setiap pengikut semua agama. Oleh karena itu, bahwa ketika umat berbagai agama mencari suatu communicatio in sacris yang multi-iman, maka kini mereka juga bisa berbagi pengalaman dan bahasa religius mereka dalam praksis konkret dari spiritualitas global dan upaya menegakkan keadilan bagi manusia dan lingkungan seperti yang dituntut tanggungjawab semacam itu. ${ }^{86}$

Dengan cara ini, genjatan senjata tidak hanya terjadi di kalangan elit pemerintah (seperti pada kasus deklarasi Malino), tetapi sampai ke masyarakat gras root. Permusuhan pun tercabut dari akarakarnya. Secara PAK, dialog yang dimaksud di atas dapat dipahami seperti yang disulkan oleh Freire bahwa dialog adalah perjumpaan di mana refleksi dan tindakan yang disatukan dari orang-orang yang berdialog dialamatkan ke dunia yang perlu diubah dan dimanusiakan. Dialog juga bukan perdebatan yang bersifat agresif dan polemik di antara orang yang berbicara; tidak bermaksud untuk mencari kebenaran, tetapi sebaliknya untuk melaksanakan kebenaran mereka sendiri. ${ }^{87}$ Kalau begitu, tidaklah salah ketika Hans Kung berpedapat: "there will be no peace among the nations without peace among the religions and no peace among the religions without dialogue"

\footnotetext{
${ }^{86}$ Lumbantobing, Reinhard. "Satu Bumi Banyak Agama: Dialog Multi-Agama dan Tanggung Jawab Global." https://reinhardlumbantobing. wordpress.com satu-bumi-banyak-agama-dialogmulti-agama-dan-tanggung -jawab-global/ (diakses tanggal 27 Juni 2016).

${ }^{87}$ Freire, Op. Cit., 77.
} 


\section{Kesimpulan}

Peran tradisi hospitalitas dalam budaya sintuwu maroso dan padungku untuk pendidikan perdamaian dalam mengatasi konflik Poso ada pada jiwa dan nilai-nilai dari kedua budaya itu. Jiwa dan nilai-nilai dari kedua budaya itulah yang kemudian menjadi poin utama untuk merangkai perdamaian di Poso. Sintuwu maroso dengan jiwa tuwu siwagi tuwu malinuwu merupakan propaganda yang hebat dan sangat akurat untuk mengasut orang-orang Poso hidup dalam persatuan yang kuat. Sintuwu maroso mengajak setiap orang Poso untuk melihat dunia sekitarnya dengan cara pandang yang sama, pikiran yang sama dan jalan yang sama. Semua orang terhisab pada filosofi sintuwu maroso; persatuan yang kuat. Hal ini mengingatkan pada pepatah tua yang secara bijak berkata "bersatu kita teguh, bercerai kita runtuh".

Тижи siwagi tuwu malinuwu dalam budaya sintuwu maroso diikat oleh benang merah yang kuat, yaitu mombetubunaka (saling menghormati/menghargai). Jadi, setiap aktivitas/kegiatan dalam tuwu siwagi tuwu malinuwu merujuk pada mombetubunaka. Akibatnya, tidak ada orang lain yang bisa beraktivitas seenaknya, karena dia adalah bagian dari komunitas. Apa yang diperbuat oleh seseorang berdampak pada komunitas. Mombetubunaka inilah yang kemudian mengatur dan mengendalikan cara hidup seseorang dalam sintuwu maroso. Sekaligus melalui mombe tubunaka setiap orang diberi peluang secara sama dan diterima serta diakui secara sama pula. Di dalam mombetubunaka itu ada keterbukaan untuk saling mengakui kesalahan. Rekonsiliasi terjadi jika kedua pihak saling mengakui dan mengampuni kesalahan. Artinya mombetubunaka mengarah pada sikap rekonsiliasi; di mana setiap orang memahami dan memaklumi tentang kejadian kelam di masa lalu. Semakin teranglah bahwa jiwa sintuwu maroso seperti itulah yang benar-benar berperan dalam mengatasi konflik Poso. Sintuwu maroso menyadarkan bahwa jikalau mereka bersatu, mereka dapat mengalahkan konflik, jikalau mereka saling mombe tubunaka mereka dapat menciptakan damai bersama.

Demikian halnya dengan budaya padungku. Budaya itu bukan sekedar seremonial ucapan syukur atas keberhasilan panen/usaha/pekerjaan, bukan juga sekedar soal menu makanan, tetapi budaya itu adalah perayaan dari kehidupan itu sendiri. Dalam perayaan itu semua orang diterima. Setiap orang dapat bergembira, bernyanyi bahkan menari bersama. Tidak ada sekat pemisah kecuali soal aturan makanan; orang Islam menyantap makanan khususnya dan orang Kristen menyantap semuanya. Kebutuhan 
yang dasariah dari kehidupan, yaitu makan tersedia pada hari raya padungku.

Di samping bertemunya anggotaanggota keluarga yang jauh, yang paling dahsyat dan fantastis dari padungku adalah bertemunya orang-orang yang saling tidak mengenal. Masyarakat dari gunung dapat bertemu dengan masyarakat pelaut di meja makan. Masyarakat petani dapat bertemu dengan pedang. Masyarakat biasa dapat bertemu dengan penjabat. Islam - Kristen dapat berjabat tangan. Tidak ada perasaan canggung, minder ataupun bangga karena latar kehidupan, semua orang merasa sama karena semua orang datang untuk merayakan kehidupan. Mereka yang ada di sekeliling meja makan itu merasa diikat bersama menjadi satu keluarga atau satu komunitas. Tidak ada perintah untuk saling memperkenalkan diri, semua akan terjadi secara alami. Menu makanan adalah media dalam pertemuan padungku. Kualitas utama dari pertemuan itu adalah silaturahmi kehidupan. Menu makanan menghantar orang-orang 'asing' itu untuk duduk bersama dalam kegembiraan untuk berdialog ringan tentang kehidupan (mealtable sharing). Topik yang paling banyak disharingkan pada padungku akhir-akhir ini adalah nostalgia manisnya kehidupan sebelum kerusuhan berdarah di Poso sekaligus keinganan untuk meracik dan menemukan kembali manisnya kehidupan itu. Meja makan padungku dapat mempertemukan 'musuh' dan 'teman' untuk meresolusi kehidupan. Di meja makan padungku tidak diperlukan sosok militer (pendekatan yang dominan dalam konflik Poso) sebagai algojo mediasi untuk resolusi konflik. Meja makan padungku adalah taman kehidupan. Inilah tradisi meja makan (talk table) di Poso dan inilah juga peranan padungku untuk perdamaian di Poso. 


\section{Daftar Pustaka}

\section{Buku Bacaan}

Antone, Hope S.Pendidikan Kristiani Kontekstual; Mempertimbangkan Realitas Kemajemukan dalam Pendidikan Agama. Jakarta : BPK Gunung Mulia, 2010.

Badan Pusat Statistik. Hasil Olah Cepat Penduduk Indonesia Menurut Provinsi, Kabupaten/Kota, dan Kecamatan; Sensus Penduduk 2010. Jakarta: Badan Pusat Statistik, 2010.

Borg, Marcus J. Kali Pertama Jumpa Yesus Kembali: Yesus Sejarah dan Hakikat Iman Kristen Masa Kini, terj. Ioanes Rakhmat. Jakarta: BPK Gunung Mulia, 2000.

Brown, Colin, The New International Dictionary of New Testament Theology. Grand Rapids, Michigan: Zondervan Publ. House, 1978.

Costello, Robert B. et al. (ed.) The American Heritage College Dictionary $3^{\text {rd }}$ Edition. 1993.

Departemen Pendidikan Nasional, Kamus Besar Bahasa Indonesia Edisi Ke-IV. Jakarta: PT Gramedia Pustaka Utama, 2008.

Dinas Kependudukan dan Catatan Sipil Kabupaten Poso. Data Pendudukan Kabupaten Poso Triwulan IV Tahun 2015; Keadaan Bulan Oktober sampai dengan Desember 2015. Poso: Pemda Poso, 2015.

Eckardt, A. Roy. Menggali Ulang Yesus Sejarah; Kristologi Masa Kini, terj. Ioanes Rakhmat. Jakarta: BPK Gunung Mulia, 2000.

Encyclopedia of Religion. Provo, Utah: Macmillan Publishing, 1955.

Fountain, Susan. Peace Education in INICEF. New York: United Nations Chhilder's Fund, Juli 1999.

France, R.T. Yesus Sang Radikal; Potret Manusia yang Disalibkan. Jakarta: BPK Gunung Mulia, 2000.

Freire, Paulo. Pedagogy of the Oppressed. Harmondsworth: Penguin, 1982.

Galtung, Johan. "Form and Content of Peace Education." dalam Encyclopedia of Peace Education, Peny. Charlotte, Monisha Bajaj. NC: Information Age Publishing, 2008.

Groome, Thomas H. Christian Religious Education - Pendidikan Agama Kristen. Jakarta: BPK Gunung Mulia, 2010.

Hagni, Feriningsih B.P. "Pendidikan Perdamaian Melalui Pendekatan Tradisi Hikmat." Tesis M.Th., STT Jakarta, 2011.

Hakh, Samuel B. "Pelayanan Perdamaian Menurut Paulus dan Implikasinya dalam Konteks Indonesia.” Orasi Ilmiah STT Jakarta, 2004.

Hakh, Samuel B. Damai Itu Meneduhkan: Suatu Tinjauan Teologis Alkitab. Bandung: Jurnal Info Media, 2006. 
Harris, Ian M. "History of Peace Education." dalam Encyclopedia of Peace Education. Peny. Charlotte, Monisha Bajaj, 16 (NC: Information Age Publising, 2008).

Harris, Ian M. "Peace Education Collage and University." dalam Encyclopedia of Violence, Peace and Conflic, Volume 2, 679. Milwaukee: University of Wisconsin-Wilwaukee, 1999.

Harris, Ian M. Fashion Me A People. Louisvelle: John Knox Press, 1989.

Harris, Ian M. Peace Education Theory. Milwaukee: University of Wisconsin-Wilwaukee, 2002.

Hasrullah. Dendam Konflik Poso; Konflik Poso dari Perspektif Komunikasi Politik. Jakarta: Gramedia Pustaka Utama, 2009.

Hastings, James. Encyclopedia of Religion and Ethics Vol. VI. New York: Charles Scribner's Sons, 1951.

Hershberger, Michele. Hospitalitas-Orang Asing: Teman atau Ancaman? Jakarta: BPK Gunung Mulia, 2009.

Ibrahim. Metodologi Penelitian Kualitatif: Panduan Penelitian Beserta Contoh Proposal Kualitatif. Bandung: CV Alfabeta, 2015.

Kamus Besar Bahasa Indonesia. Jakarta: Gramedia Pustaka, 2011.

Karnavian M., Tito. Indonesian Top Secret; Membongkar Konflik Poso. Jakarta: Gramedia Pustaka Utama, 2008.

Kartadinata dalam Latifah, Pipih., peny. Pendidikan Kedamaian. Bandung: PT Remaja Rosdakarya, 2015.

King Philip J. \& Lawrence E. Stager. Library of Ancient Israel: Life in Biblical Israel. London: Westminster John Knox Press, 2001.

Kruy. J. Kabar Keselamatan di Poso. Terjemahan P.S. Naipospos. Jakarta: BPK Gunung Mulia, 1977.

Kruyt, A.C. Keluar dari Agama Suku Masuk ke Agama Kristen. Terjemahan Th. Van den End. Jakarta: BPK Gunung Mulia, 1976.

Latifah, Pipih., peny. Pendidikan Kedamaian. Bandung: PT Remaja Rosdakarya, 2015.

Lempp, Walter. Tafsiran Alkitab Perjanjial Lama Jilid 3: Kejadian 12:4-15:18. Jakarta: BPK Gunung Mulia, 1989.

Manyonyo, Y. "Kebudayaan Tana Poso." Dalam Wajah GKST: Buku Kenangan 100 Tahun Injil Masuk Tana Poso. Dj. Tanggerahi, 105-118. Tentena: Majelis Sinode GKST, 1992.

Mulder, D.C. Tafsiran Kitab Yosua. Jakarta: BPK Gunung Mulia, 1990.

Nurcholish, Ahmad. Peace Education \& Pendidikan Perdamaian Gus Dur. Jakarta: Elex Media Komputindo, 2015. 
Pazmino, Robert W. Fondasi Pendidikan Kristen. Jakarta: BPK Gunung Mulia, 2012.

Pohl, Christine D. "Responding to the Strangers; Insight from the Christian Tradition." dalam Studies in Christian Ethics 19.1. London: SAGE Publication, 2006.

Pohl, Chritine D. Making Room: Recovering Hospitality as a Christian Tradition. London: Westminster John Knox Press, 2008.

Poreadaminta, Kamus Besar Bahasa Indonesia. Jakarta: Balai Pustaka Utama, 1981.

Richards, Lawrence O. Christian Education: Seeking to Become Like Jesus Christ. Michigan: Zondervan Publications, 1975.

Sembiring, M.K. (ed.). Pedoman Penafsiran Alkitab; Surat Yakobus. Jakarta: LAI-Yayasan Karunia Bakti Budaya Indonesia, 2009.

Simarmata, Harun Darmawanto. "Hospitalitas: Warisan Tradisi Kristen; Meretas sebuah Model Pendidikan Kristiani bagi Kehidupan Bergereja di Dunia yang Penuh Perbedaan.” Tesis M.Th., STT Jakarta, 2010.

Suryana \& Rusdiana. Pendidikan Multikultural: Suatu Upaya Penguatan Jati Diri Bangsa. Bandung: Pustaka Setia, 2015.

Telushkin, Rabbi Joseph. Jewish Literacy. USA: HarperCollins Publisher, 2001.

UNESCO. Constution of the United Nations Educational, Scientific and Cultural Organization. London: UNESCO, 1954.

Wahyudin dalam Latifah, Pipih., peny. Pendidikan Kedamaian. Bandung: PT Remaja Rosdakarya, 2015.

Wrobleski, Jesica. The Limits of Hospitality. Minnesota: Liturgical Press, 2012.

Zonnoni, Arthur E. Jesus of The Gospel: Apa Kata Injil tentang Dia. Jakarta: Penerbit Obor, 2004.

Zwiwerblowsky, R.J. \& Geoffrey Wigoder. The Oxford Dictionary of the Jewish Religion. New York: Oxford University Press, 1997.

\section{Wawancara}

Hokey, Yustinus. Wawancara oleh penulis. Poso (Tentena), Indonesia, 16 Mei 2016.

Ompi, Hengky. Wawancara oleh Penulis. Poso (Tentena), Indonesia, 16 Mei 2016

Santo, J. Wawancara oleh penulis. Poso (Maliwuko), Indonesia, 29 Mei 2016.

\section{Website}

Adiprasetya, Joas. "Hospitalitas: Wajah Sosial Gereja Masa Kini." http://gkipi.org/hospitalitas-wajah-sosial-gereja-masa-kini/ (diakses tanggal 18 Februari 2016). 
Amsa, Saefudin. "Damai itu Apa? Sekilas Pendidikan Perdamaian." http://umum.kompasiana.com/2009/06/17/damai-itu-apa-sekilas-pendidikan perdamaian-7205.html (diakses tanggal 12 Maret 2016).

Lumban tobing, Reinhard. "Satu Bumi Banyak Agama: Dialog Multi-Agama dan Tanggung Jawab Global.” https://reinhardlumbantobing. wordpress.com satu-bumi-banyakagama-dialog-multi-agama-dan-tanggung -jawab-global/ (diakses tanggal 27 Juni 2016).

Marimbo, Rizal Calvari. "Pemuda Poso Siap Masuk Hutan." www.metrosulawesi.com/article/pemuda-poso-siap-masuk-hutan (diakses 23 Juli 2015).

Marriam Webster An Encyklopaedia Britanicca Company. "Learner's Dictionary." http://www.learnersdictionary.com/ (diakses tanggal 16 Maret 2016).

Wikipedia. "Pendidikan.” http://id.wikipedia.Org/wiki/Pendidikan (diakses 12 Maret 2016) 